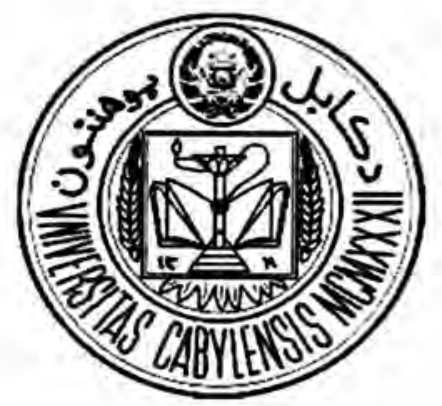

$$
\begin{aligned}
& \text { وزارت تحصيلات عالى } \\
& \text { بو هنتون كابل } \\
& \text { يوهنحى روانشناسى و علوم تربيتى هئي } \\
& \text { دييارتمنت روانشناسيى } \\
& \text { مونوكر اف دورة ليسانس } \\
& \text { انواع و اقسام صرع } \\
& \text { Kinds of Epilepsy }
\end{aligned}
$$

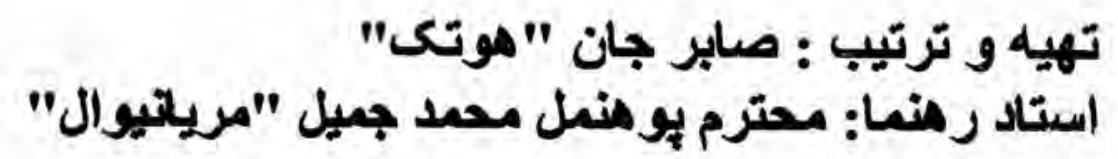

سل: به ri 


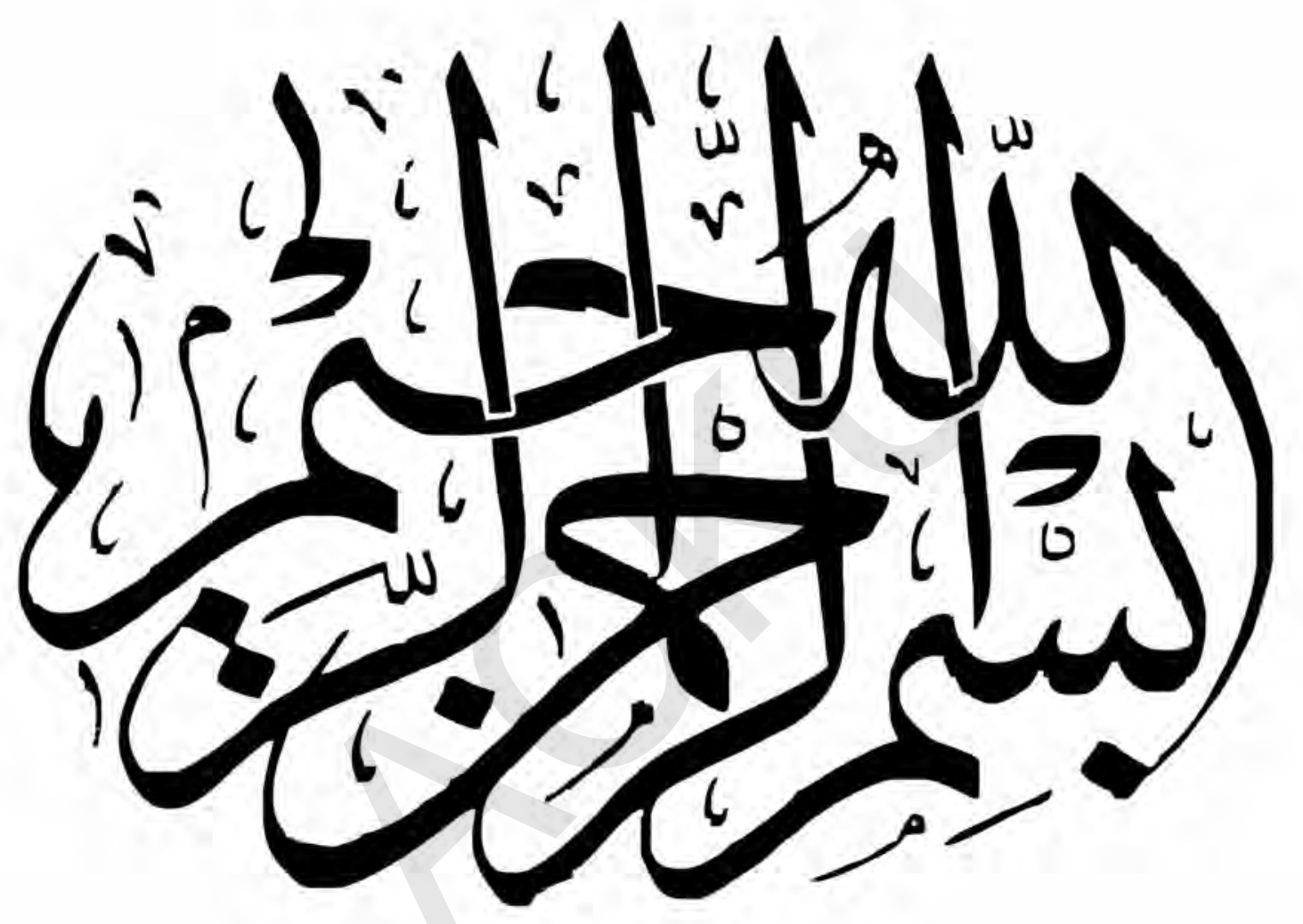




\section{تهرست مطالب}

صفحات

عناوين

1

فهرست مطالب

3

مقدمه

5

صرع Epilepsy

6 علل بيمارى حرع:

8 انواع صر ع وحملات آن:

10 تاريخجه صرع:

10 وجا سبب:

11 عامل وراثتى:

12 عامل عضوى:

14

15 فزيولوزى: اشكال بالينى:

16 علانيم بالينى:

18 مر عيرعى (ميرك)

22

نوع كوجى يا Patetmal

22 نوع جكسونين Jaksonin

22 حملات موضعى:

23 حمله صرع روانى - حركى:

24 فزيولوزى وفارمكالورَى صرع: 

الف : تظاهر ات حركتى: حالت عمومى مبتلايان بصرع. حالت روحى خوش: حالت روحى عادى 


\section{مatid}

طورى كه مبدانيم، روانشناسى علم حياتى بوده وارتباط مستقيم بازندكى روزمره داشته وانسان خود جز از محيط بيولوزيك آن بشمار مى رود، جون انسان ها موجود اجتماعى اند

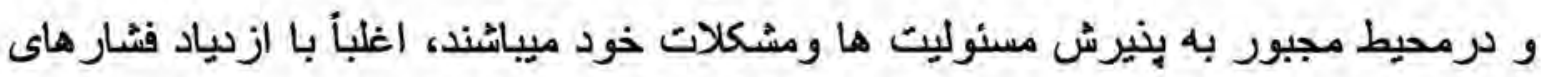
زياد مبتلا به امر اض روانى ميكردند، البته امراض روانى انواع مختلف داثته كه از جمله مينوان صر ع يا ميركى ران مبام برد.

مريضى صرع از جمله طولانى ترين امراض درتاريخ طبى به مقايسه امر اض ديكر به حساب مى آيد، كه سالها قبل آنرا بنام مرض (مقد) ياد ميكرند، زيرا تصور ميشد، كه ني اين مرض به اثر خصوصيات كه مقس شمرده ميشّد روى كار ميآيد، بعدا اين مرض را شيطانى نكر نموده كه ارواح خبيثه درمغز بيمار حلول نموده خوشبختانه كه امروز درزمينه شُناخت وتداوى اين مرض اقداماتى صورت كُفته وتداوى موثر را درياقت نموده وتواتسته اند، براى فاميل ها وافر اد كه دجار اين عارضه اند كمك نمايند، مرض صر عرع اختلالى است كه به سيستم عصبى ارتباط دارد كه در اثر بى نظمى درمغز رخ ميدهد، واساسا با از دست دادن حالت شعورى ويا اختللال درحالت شعورى توأم مياشد، خصوصيات حالت اختلالى يا ميرگى كرفتخى با اشكال مختلف صورت ميكيرد كه مربوط ومنوط به ماهيت محركات

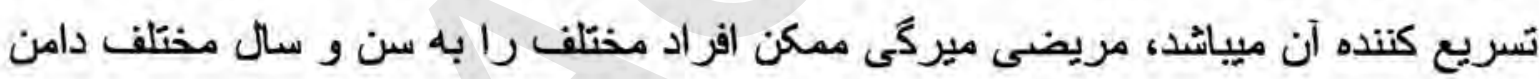
كير شود، كه تمام نزاد هاى بشر به اين مرض بدون كدام مقاومت كرفتار شده مينوانند همجنين عوارض اين مرض بين مرد وزن يكسان است و شيوع اين مرض دراطفال نسبت به جوانان زيادتر است .

صرع يعنى از خود، بيخود شدن ويا بيمارى آن ناكهانى وسريع بوده كه به ثُكل حمله

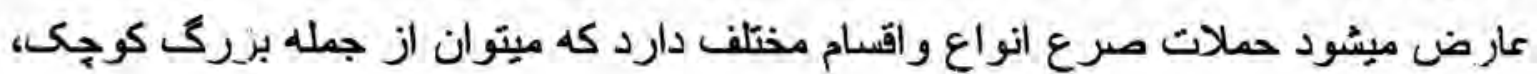
قسمى، حركى، روحى حركى، تُشنجى وغيره نام برد.

هف از تهيه اين رساله ، ايز است كه فاميل ها وساير افراد مرقسمت نكهدارى فرزندان شان توجه مبنول بدارند، زير ! ضربه هاى خارجى، امر اض مثل زردى، مننزيت و در 
صورت عدم رسيدن خون به مغز باعث بوجود أمدن اين بيمارى ميشود، البته فرديكه مبتلا به جنين عارضه ميشود بايد تحث مر اقبث وتذاوى قرار بكيرد.

جون روانشناسى استشنى وغير عادى از مضامين اساسى يوهنظى روانشناسى وعلوم

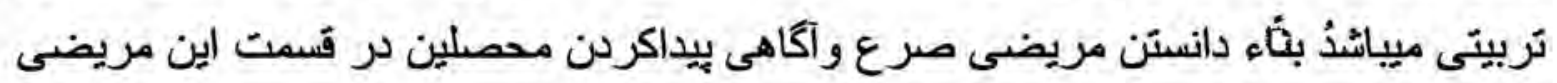
مهم بنداشته ميشود، به همين دليل خواستم تا موضوع مونوكراف خويش را تحت عنوان، "انواع واقسام صرع" انتخاب نمايم .

درزمينه امر اض روانى آتار زيادى وجود دارد، كه شامل كتاب منابع ايرانى وترجمه شُهـ اززبانهاى خارجى ميباشد.

اين مونوكر اف تحقيقى كه بيشتر مطالب آن به اساس تحقيق كتابخانه يى تكميل كرديده است وعلاوه برمواد كتابخانه يى از رساله ها وكتاب هاى نويسندكان روانشناسى كلينيكى كانه

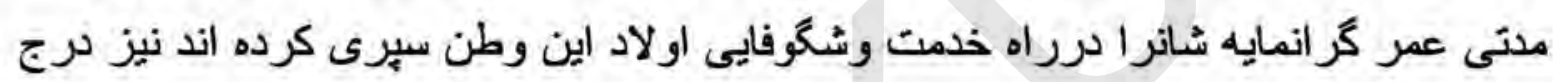

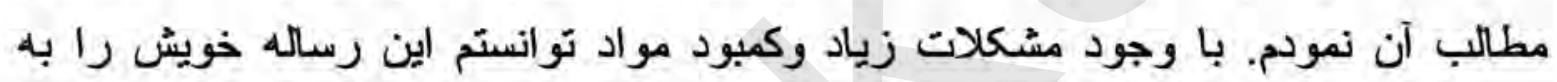
همكارى استادان به بايِه اكمال برسانم.

$$
\text { با احتر ام }
$$

صابر جان "هوتكى" 


\section{صرع Epilepsy:}

صرع به معنى از خود بيخود شدن ونام عارضه انى است كه دانشمندان مغرب زمين آنرا (إيى لبسى) Epilepsy نام نهاده اند، ودراصطلاع يونانى به معنى ربودن ميباشد، واولين بار اين بيمارى توسط نام "امبرو" شناختّه شُه همجنان اين بيمار نزد حكمايى رومى بنام (مريوس ساز) يا بيمارى مقدس يا كومى سياسيل ناميده ميشد.

صرع از جمله ضايعات عصبى است، كه حالت تشنجى وعود كننده مبياشد اين بيمارى از جمله صو لانى ترين امر اض درتاريخ طبابت به مقايسه ساير امراض ميباشد، اين بيمارى از جمله كَشته ها تا به امروز به نام هاى مختلف ياد كرديده است. زمانى آنرا مرض مقدس ياد ميكردند، زير ا تصور ميشد اين بيمارى به اثر خصوصياتى كه مقس شمرده ميشود به وجود مى آيد.(3: 230).

بعدا آنرا به خصوصيات شيطانى نسبت دانند . يعنى فكر مى شد كه ارواح خبيثه در مغز اين اشخاص حلول مينمايد .

بعضى از علماى طب عقيده دارند، كه سور اخ هاى درجمجمه انساتهاى قديم يافت شده اند، همان عقيده را نشان ميدهد، كه طبييان آن زمان به ائر سوراخ كردن جمجمعه كسانيكه به مرض صرع گرفتار بوند، به اصطلاح ارواح خبيثه را از مغز آنها خارج مى ساختند، همجنان نام هاى مختلف و نظريه هاى مختلف درقسمت اين بيمارى بيشنهاد شُده است، جنانجه درمحيط ما به نام ميرگى اين بيمارى شُناخته شُده است، اين بيمارى امكان دارد افراد مختلف را به سن وسال متفاوت دامنكير شود، تمامى نزاد هاى بشر بدون استناء كرفتار شده ميتو اند. (3: 230).

هدجنان عوارض اين بيمارى بين زنان ومردان يكسان است شيوع اين بيمارى در اطفال بييشتر است، درحودى 50 فيمد دراطفال كمتر از 15 سال ديده شده است. كه افراد ميتلا به مرض ميرگى هم نورمال وهم غير نورمال بوده اند. بيمارى مرع مر نفوس عمومى جهان تقريبا 1.4 فيصد افرادى كه براى بار اول به شفاخانه هاى صحت روانى مراجعه 
ميكنند به افرادى سايكوتيك ارتباط دارند ولى نبايد فكر كرد كه كويا مرض صرع باعث ديو انكى ميشود. (3: 230)

\section{علل بيمارى صرع:}

تقريبا هرنوع ضربه ايى كه به مغز وارد شود، مينواند باعث حمله هاى صرعى شود از شايع ترين علل صرع ميتوان عو امل نيل را نام برد.

1. صدمه مغزى دراثناى ولادت يا دراوايل زنده گى همجنان درائر فقدان اكسيجن

$$
\text { وزردى شديد }
$$

2. بـائين بودن ميزان قند خون

3. امراض وخيم مكروبى مغز درنزد اطفال يا اشخاص بزرگَسال كه منتج به مندمه

مغزى كردد

$$
\text { 4. - موجوديث تومور درمغز }
$$

5. جر احت يا جمجمعه با صدمه شديد مغزى تورئ

6. علل ناشناخته (1: 231)

هركاه فرض نمائيم، كه لليل اساسى صرع به مغز ارتباط دارد يا اينكه عو امل ديكر باعث اختلافات ميكردد، بايد تفاوت بين عوامل كه مرانسان اختلالات را به وجود مى آورد وعو املى كه اختلالات را سرعت ميخشُد واضع كردد، به طور مثال كسانى كه دواهاى معين ازقبيل استركينين را استعمال ميكند، درصورت مشاهده صرع دجار حملات اختلالى ميكردد، همجنان اختلالات زمانى به وجود مى آيد كه مغز توسط جريان مسنقيم برق تحريك ميشود ويا اينكه مقدار قند خون به سطح بانيز برسد ويا اينكه دفعتاً نخيره خون وجريان آن درمغز به سكتكى مواجه كردد . همجنان عواملى زياد وجود دارد كه اختلالات را رراشخاص مصاب به صرع سرعت ميدهد، اين حالات به سبيى است كه بالاى نقايص وارد شده درمغز تاثير سوء مى كذارد و يا اينكه عوامل مذكور ارثى ميباشد بسيارى از عوامل كه اختلالات را سرعت مييخشد، فكر ميشود كه قابليت نفوذ در ليوار هاى حجروى سلول هاى مغز آب ، قند ، نمك منرال و اكسيجن را از جريان خون جنب نمايد را تغير 
ميدهد ـ اين خصوصيت (قابليت نفوذ) باعث ميشود، كه سلول هاى قبل كاربن داى اكسايد

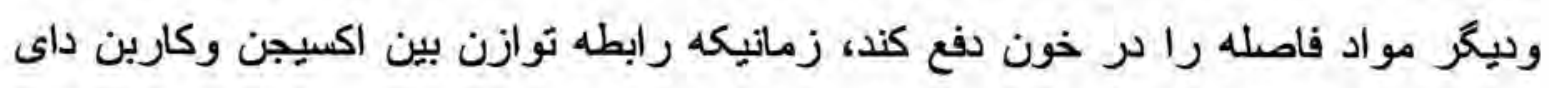

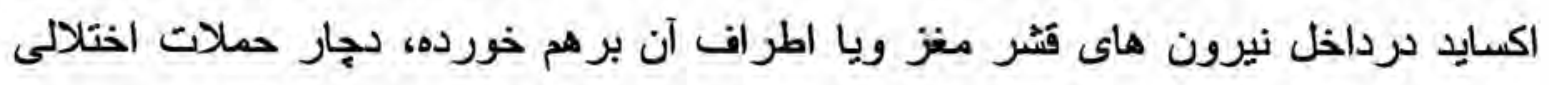

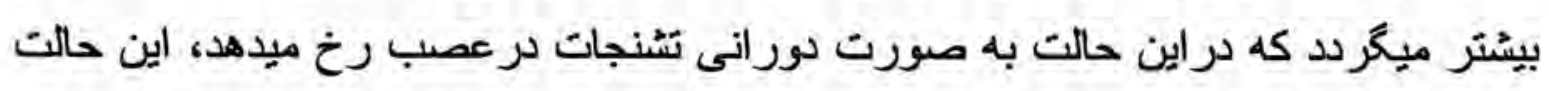

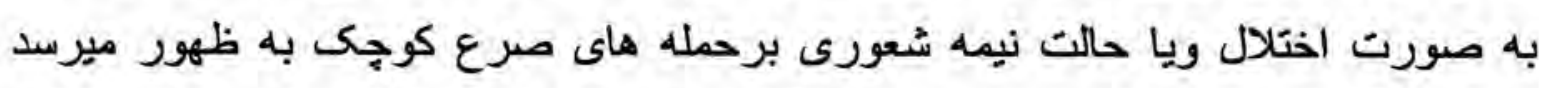

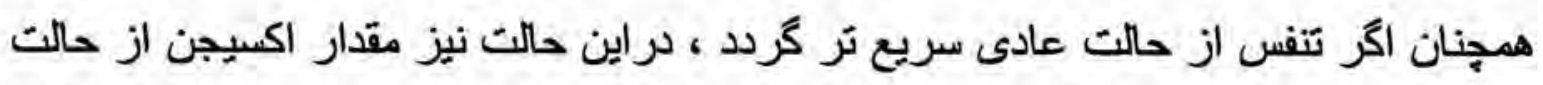

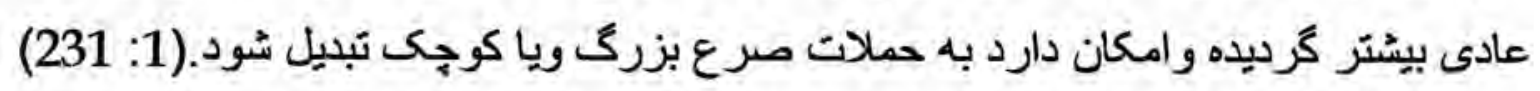
از ساليان دراز به اين سو فهميده شده است كه توازن آب دربن مستقيما برحملات صرع

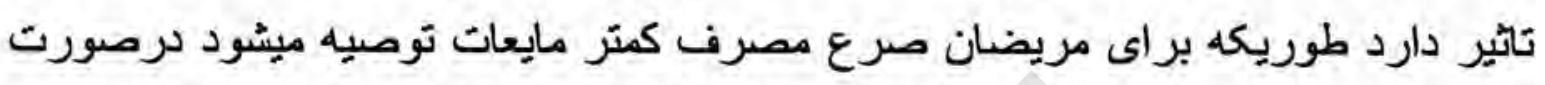

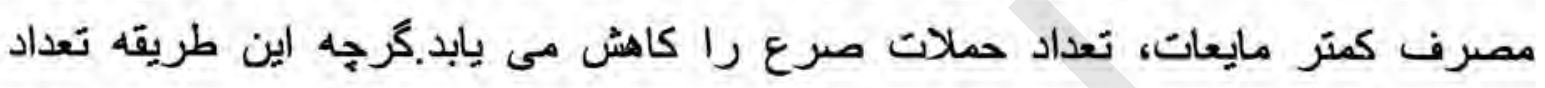

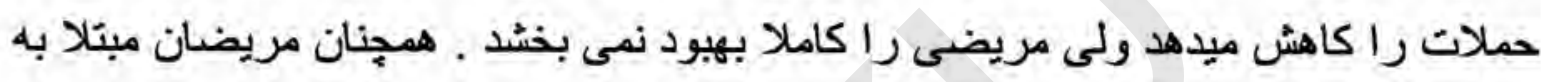

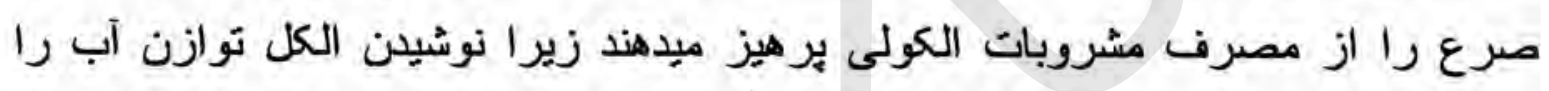

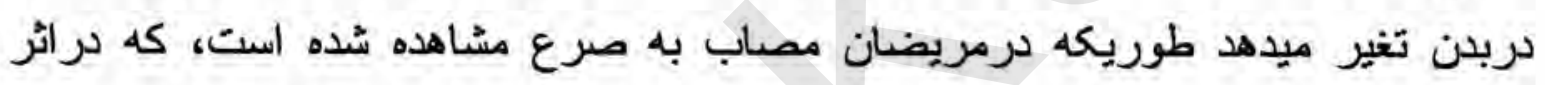

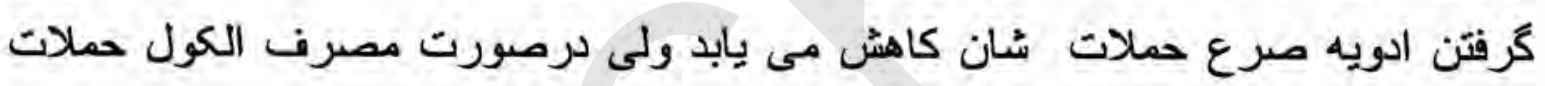
دوباره به ظهور ميرسد.

فثار هاى روانى ، كسالت هاى روزمره نيز تعداد حملات صرع را سرعت مى بخشّد بنا

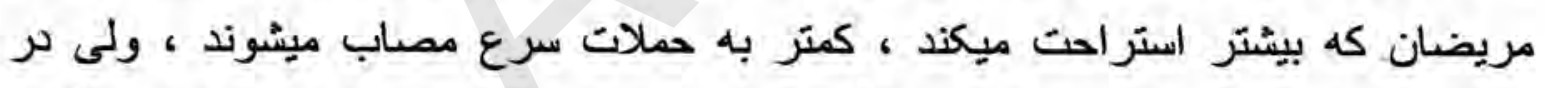

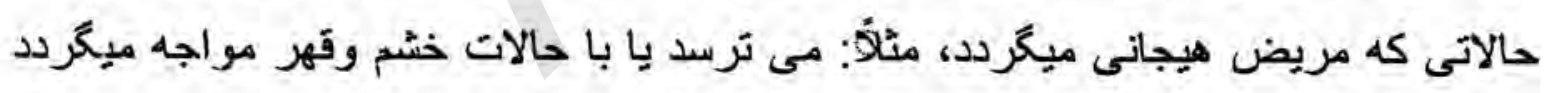

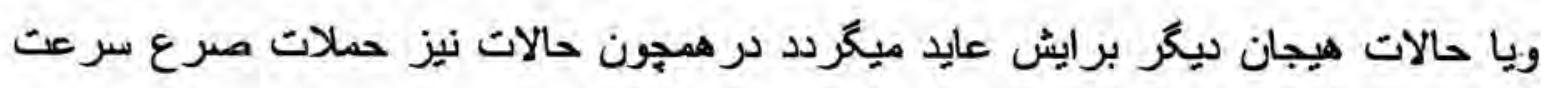

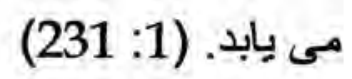

درمورد اينكه آيا صرع ارثى است يا خير؟ بحث هاى فراوان صورت كرفته است مثلا

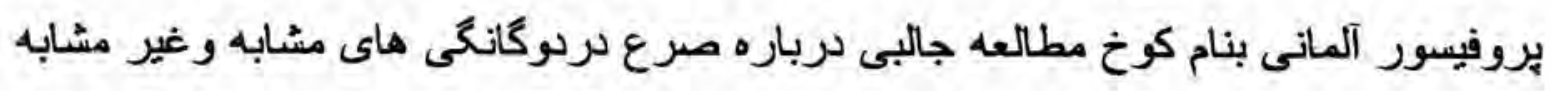

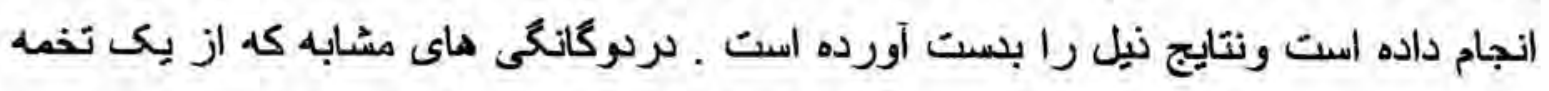

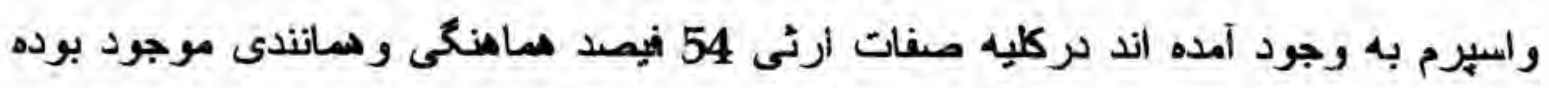

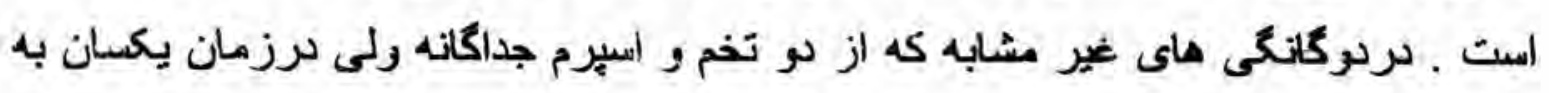


وجود آمده اند. 10 فيصد آنها داراى هماهنگى وهمانندى درصفات ارنى بودند و 90 فيصد همانندى نداشتند كه رينتيجه نميتوان عارضه صر ع را دراين مورد كاملا ارثى دانست زيرا معلوم نيست به جه علث 46 فيصد از دوكانه كى هاى مذكور كه دركليه تقسيمات ارثى شركت مساوى دارند از برخى صفات مشترى وهمانند محروم مى مانند از طرف ديگر آن 54 فيصد كه صفات مشابه نشان ميدهند عوارض مغزى ررآنها بيشتر به علت اثرات محيط است و يا اثرات وراثت .

روانشناسان بيخر به نام هاى كونارد Konard لينوكس lenvox نيز درمطالعاتى كه راجع به امكان ارثى بودن صر ع نموده اند ، ملاحظه شده است كه دوكانكى هاى مشابه تقريبا 87 فيصد داراى شباهت ارثى ميباشد.

وقتى يكى از والدين به يكى از انواع صرع كرفتار باشد امكان دارد (5-6) فيصد اطفال اين والدين به يكى از انواع صرع كُرفتار شوند ولى علت اصلى معلوم نيست مطالعات اخير نشان داده است كه رححدود 40\% فيصد افراد روى زمين مبتلا به انواع صرع ميباشد.

\section{انواع صرع وحملات آن:}

كرجه حملات صرع انواع زياد دارد اما بيشتر از دونوع آن نام برده ميشود حملات عمومى وحملات موضعى ، حمله عمومى وقتى شروع ميشود كه تخليه برقى سلولهاى درقسمت بزركى از مغز صورت كيرد وحمله موضعى موقعى آغاز ميشود كه تنها قسمت كوجكى از مغز دجار تخليه برقى شده باشد. ربين اين دو نوع اشكال فرعى ديكرى نيز طبقه بندى هورئ شده اند.

نوع حمله صرع نظر به اينكه تغيرات برقَى دركدام ناحيه مغز واقع شود فرق ميكند. اين آزمايش توسط آله بنام الكترو وانسفالوكر اف (EEG) يا آله مثبت گر اف امواج برقى مغز 
حمله صرع ممكن است به شكل حمله بزرى يا حمله كوجى با صرعى ويا به شكل معادلات صرع عرض اندام كند علايم بالينى ضايعات منطقه صرعى به سه حصنه تقسيم

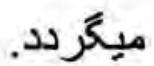

باى تعريف صرع درميان مى آيد همه از خود سوال مى نمايند كه آيا ميرگى يكى مرض است يا يك عرض .

درحاليكه عرض آنست كه درجريان يك مرض كه سبب معين ميداشته باشد بحيث از تظاهر ات آن خود را نمايان ميسازد.

اكر حمله كوجى باشد مريض وقتا به زمين افتيده دوباره به حالت اولى خود مى آيد صرع هاى قسمى حمله عصبى را دار اميباشد حمله تشنجى درائر خستخى ويا خوردن غذاي عارض ميشود كه خورد وكلان به نظرميرسد.

صرع هاى ناشى ا زتب : بعضى از شيرخورن كونكان درائر تب تشنجى بيدا ميشود و همجنان اختلالات ادراك كاهى در ابتداء وزمانى درانتهاى حمله عارض ميشود ودراين صورت بيمار رنح زرد به نظر ميرسد ـ. راثر كيفيات فزيكى حمله كلى نشانى هاى نزد بيمار ممكن است ديده شود.

1. بيمار ناكهانى وسريع بوده وبشكل حمله عارض ميشود. 2. - 2. - اراده درآن دخالت ندارد.

3. تظاهرات آن از دانره شُعور خارج است كه غالبا بيمار بهيج وجه از آن همه حالات خاطره اى بياد ندارند. 4. حمله ها تكرار ميشود وموعد تكرارآن ثابت نبوده وبرحسب هر بيمارى تفاوت ميكند. 5. اين عارضه نزد هر بيمار بشكل مخصوص بوده وغالبا بطور بكسان ومشابه عرض اندام ميكند. 6. اغلب اوقات علانم عمومى اين عارضه با علانيم اختصاصى كه منحصر به بيمار است توام ميباشد . أست 
7. علانم بى ربط الكترو آنسفالو كرافى كه خاص اختلال كه منحصر به امواج

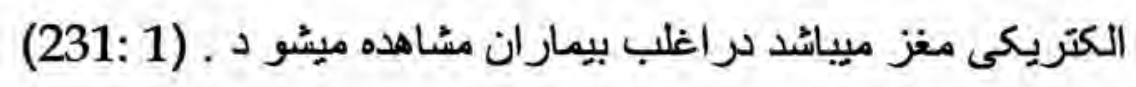

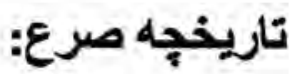

بيمارى صرع از قليم شناخته شده ومورد بررسى مفصل (جالينوس ) وهمجنان ابن سينا قرار كرفته است ولى بغير ازشرح بالينى وخصوصيات حمله صرعى كه بوسيله دانشمندان

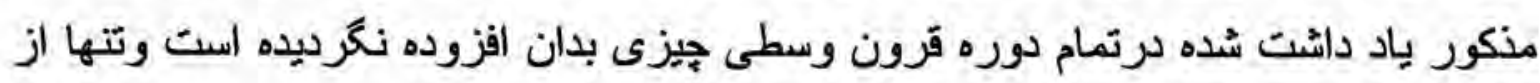
دوره رنساتس اصول تشريحى وعلمى درتوجيه اين بيمارى مثداول كرديد. درسال 1681 ويليس ويس از آن اسكيرول شرح يوشيده دراين باره نكاشته ودر سال 1827 براوه ، صرع ناشى از فلج نيم تنه ودرسال 1865 هُ لينگ جاكسون ارتباط مغز

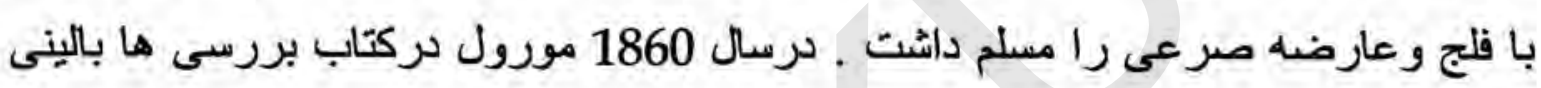
خود معادلات صرعى را متذكر شد .

اثبات فرضيه جاتناسى مغز بوسيله جاكسون راه را براى مطالعه بسيارى از علت تابع محل ضايعه ويا منطقه از مغز است كه در بوجود آوردن تظاهرات اين حالات اين كثود

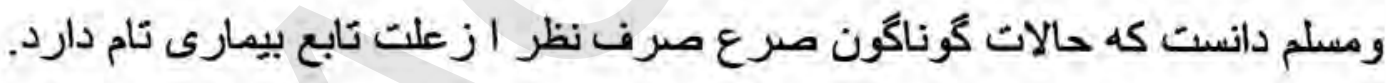

درسالهاى اخير نتِجه بررسى هاى الكترو آنسفالوكَر افى افق تازه اى براى روشن ساختّن

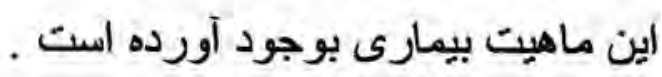

\section{وجه سبب:}

تنوع حالات بالينى صرع بهترين شاهد علل مختلف اين بيمارى ميياشد درحقِقت نه فقط علل اين بيمارى زياد است، بلكه نوع بالينى آن تابع نقطه اى از نور اكس ميياشد كه تحث تأثير

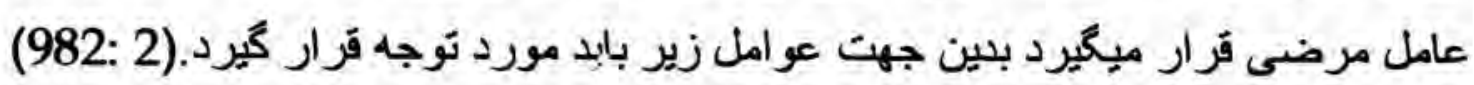


Esquirol -2

Hugling -3

Jackson -4

Braw -5

Morel. -6

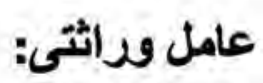

تا قبل ازقرن 19 علت اصلى صرع را ورائت ميدانستد ولى مطالعاتى كه از آن تاريخ صورت كرفته مسلم داشته كه صرع عارضه ارثى نيست كونر اد درسال 1935 ولنوكس درسال 1947 بررسى هاى روى دوكانكى هاى صرعى وديكر بيماران صرعى نم نموده

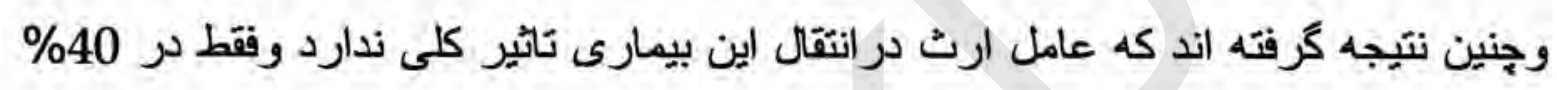
اولاد مصروعين اين عارضه مشاهده شده است.منذكر ميشويم كه دربرخى ا زبيماربهاى ارثى بيمارى كورى كه درآنها حمله صرعى ارثى بوده صر ع از جمله علانم بيمارى بشمار

همجنين از مطالعاتى هارواله درسال 1939 روى تعداد زيادى از اين بيماران نمودند هسلم كرديد كه با يشرفت تمدن ازتعداد خانو اده هاى صرعى به اندازه 50\% كاسته شده است .

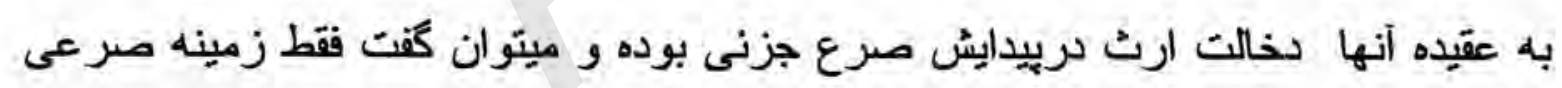
شدن را تحت تاثير عوامل مولد صرع فراهم ميسازد.

بديهى است نرصرع هاى ايديوباتيك كه هنوز على بر آن مرتبط نبيت عامل ارث را مهر

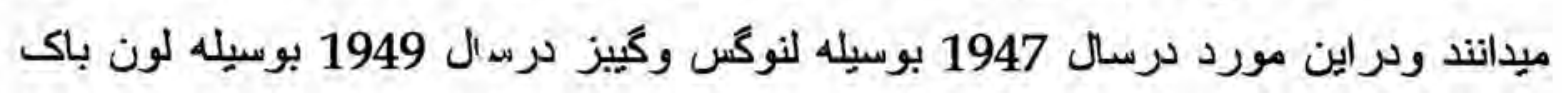
واستروس ودرهمان سال بوسيله بار را مطالعات الكترو آنسفالو كرافى بالاى اطفال جندين بردين

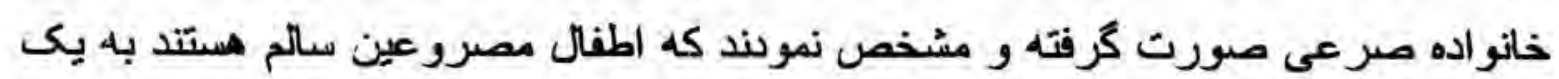
نوع ليسرتيمى مبنّلا ميياثد . 
دانشبمدان فوق معتقد شُده اند كه اين اختلال رينم امواج الكتريكى مغز را ميتوارن يكى نوع عامل زنيتيك تلقى نموده ولى هاروالد درسال 1945 تحقَيقات مفصلى دراين باره نمود واختلال ريتم مغز وخصوصيات زنتيك آنرا به عامل بيكرى نسبت داده است .

درنتيجه ميتوان كفت كه درصرع عامل ارثى تقريبا وجود ندارد ، بنابر ان موضوع ازدواج يا بار دار شدن بيماران بايد بطور عادى ومعمولى تلقى شود به خصوص آنكه تحقيقات آلستروم درسال 1950 وهاروالد درسال 1954 تحقيقات مفصلى درباره نقانص عقلى بلى فرزاندان سالم مصروعين نشان داده كه ابدا نسبث اين نقانص با فرزندان خانواده هاى سالم

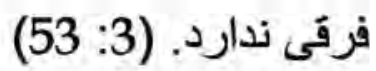

Conard -1

Harvald -2

Lowen back -3

Lennox -4

Gibbs -5

Barras -6

عامل عضوى:

روز به روز تعداد اين نوع بيمازى كه آنرا صر علامنى مينامند افزوده ميتردد بطوريكه برخى از مولفين معتقند، صرع عارضه اي است اكتسابى وناشيى از ضايعات عضوى رحال حاضر علل نيل موجود بروز حالات صرعى شناخته شده است.

$$
\text { الف - ضربه جمجمه ( طبق بررسى واتسون) }
$$

40\% افر اديكه سر هايشان درجنى جهانى دوم ضربه ديده بود دجاز اين عارضه شده اند. ب- ضايعات نسج مخ ر ائر ضرإه وخونريزى تومور

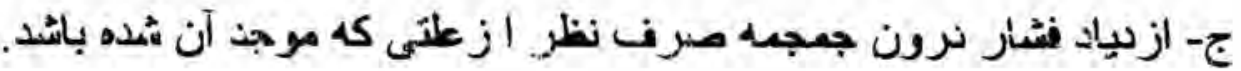


د - عفونتهاى مغزى مانند سيفيلس عصبى ، آنسفاليت ، آبسه ، مننزيت هاو غيره .

هـ اختلال گردش خون درمغز مانند خونريزى آمبولى - ضايعات جنينى عروق مانند آنوريسم آنزيوم ، آرتريو اسكلروز ( طبق بررسى هاى وايت وييلى وبيك فورد ، درسال

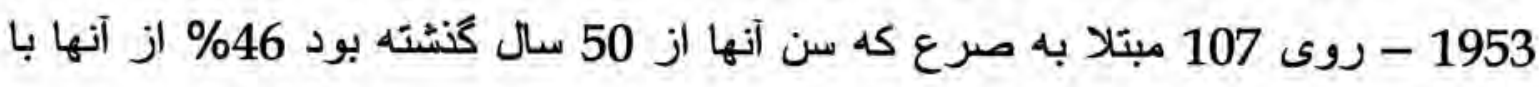
اختلالات عروقى دجار بوده اند.) و - ضايعات دززاتيف مخ - دزرنسانس سلولهاى مخ ممكن است به تتهايى باعث حمله صرعى شود وضمور قشر مخ وبيمارى بيى ، وبيمارى آنرايمد. ز- اختلافات ميتابوليك كه دراورمى وهيبيوكليسمى

ح- علل هورمونى آنجه مسلم است بِ از قاعلىى يا هنگام آبستى اين عارضه ايجاد يا تشُديد ميِردد.

طـ مسموميتها : برخى مواد سمى را صرع زا ناميده اند مانند آبسنت د آفسنطين سرب و مخصوصا الكل .

ى - عامل انعكاسى اعم از اينكه مبدا اين انعكاس از احشاء سو هاضمه سنگ صفر انى نكل امعاء و غيره ) ويا مجراى گوش " جسم خارجى مجراى كوش" باشند.

ك - عامل هيجانى وعاطفه ى كه درتعقيب شنيدن صدا با شوك يا موسيقى بوجود آيد (كريجلى ) ل - عامل آنافيلاكسى وشوك كلونيد وكلازى. 3- عوامل خارج مغز ى : منظور ما از اين سته عللى است كه محل آنها درخارج نور اكس است باعت اختلال عمل نوران هاى مغزى شده ودرحقيقت ميثوان موجلصر عى را بوجود مياروند و رحقيقت ميتوان كثت دراين حالات مغز واسطه اتى ميانه علل بيمارى ورنظاهرات آن ميياشد ومسلم است بكون دخالت مغز بروز حملات امكان بنير نيست أين سعته علل

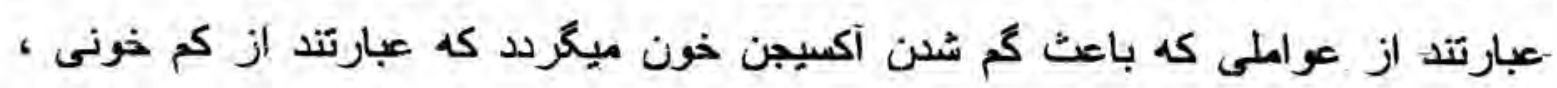


اختلال هموكلوبين يا بندى تنفس يا ارتباط خون شريان ووريد يا كم شدن قوه قلب وامر اض قلبى ديكر مانند استوكس آدامس ، احتقان قلب ، سندرم سينوس كاورنو، بدى ساختمان مانر زاد قلب يا كمى فشار خون همجنين ممكن است كمى آكسيجن از كيفيات ميتابوليك تب بيا ازدياد ترشح تيروئيد ) يا كمى خون (آنسولين ) ترابه يا كم شدن كلسيم خون ( دوره هاى

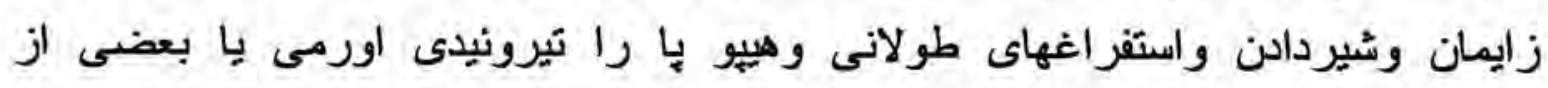
مسموميتهاى اوكسيدركرين وغيره )ناشى كردي.

4- عامل مجهور - صرع اصلى (دايديوياتيك) منظور از اين نوع صرع نوع حالتى اسث كه درآن علتى كه بتواند بيمارى را توجيه كند بدست نيايد . به عقيده ما اين تعريف براى صرع كافى نيست بلكه عقيده داريم كه صر ع اصلى بايد دار ایى خصوصيات زير باشُد. 1. 1. بروز حمله درسنين مشخص. 2. فقدان عارضه عصبى و على كه ممكن است موجه صروع تلقى شود. 3. وجود زمينه خانوانگى وروانى 4. وجود نمودار الكترو آنسفالو كر افى مشخص وردئ اين بيمارى 5. حساسيت شديد بيمارى به عوامل آزمايشى ودارونى مولد صر ع مانند كاربيازول .

\section{باتونى ميكاتيسم وفيزيويالمزُى صرع:}

از جهت باتوزنى مسلم است كه اين عارضه دراثر اختلال عمل نورونى مغز بوجود ميايد نياز به توضيع نيست كه سلولهاى مخ ، عاليترين وكاملترين مراحل خلقت را بيموده وتعداد بردي آنها كه بالغ بر 13 ميليون ميياشد دريرتو همكارى با يكنيكر يك سيستم ارتباطى شكفت انكيزى را بوجود ميارود كه مبدا كليد تظاهرات عصبى و روانى بشمار ميرود . جاكسون

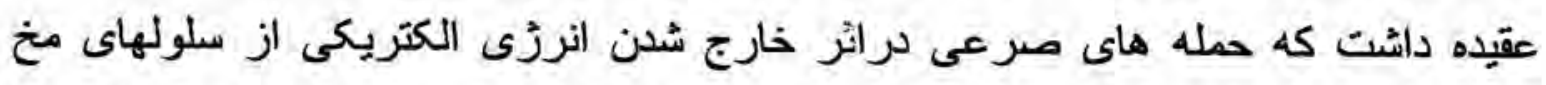
ايجاد ولى با تحقيقات كه هانس بركر در سال 1919 ولنوكس وز اسبر نموده بوند مسلد

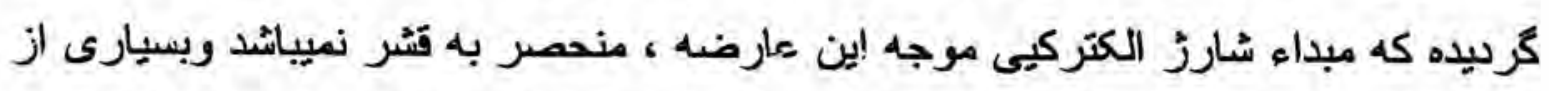

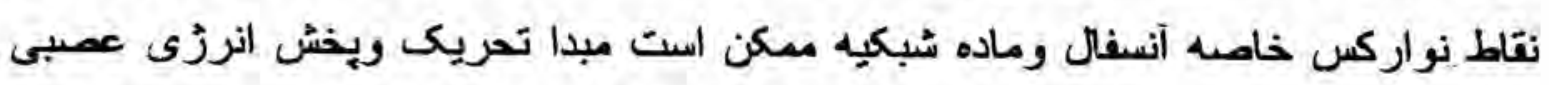
غير عادى بوده كه منعاقب آن تظاهرات بالينى صر ع بوجود ميايد. آنجه مسلم است تحريك ونى 
كه ابتدانى از نقطه اى از نواركس شروع وبه قشر مخ منتمل ميكردد وتحولاتى راكه درقشر بوجود ميارود موجه تظاهرات اين بيمارى ميشود ( شكلهاى 609 61) از جهت ميكانيسم بيدايش صرع فرضيه هاى مختلفى ابراز شده كه همه آنها از اين قرار است.

فرضيه كم خونى واختلال كرش خون در مغز - فرضيه تحريك قشر مخ فرضيه وقفه -

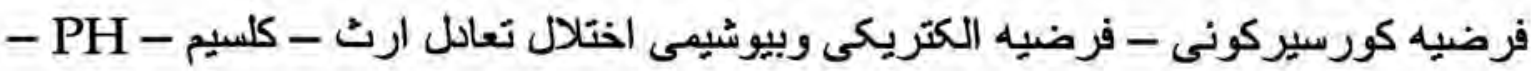
هورمون ها - تعادل اسيدوباز - تغيرات اكسيزن - تغيرات ميزان آب ، انساج - تغير قتد خون) فرضيه شوك كلونيد وكلازى ، فرضيه اختلال دستكاه نباتى وغيره . درحقيت اشكال مهم باتوزنى صرع همانا كيفيتى است كه دربسا حالات هيجكونه علتى وسبب كثف نشده است وتظاهرات بيمارى با محل وموضع آسيب مخ ظاهرا ارتباطى نداشته خاصه آنكه دربعضى حالات عامل مولد بيمارى درخارج نور اكس شُناخته شده است. علاوه براين فرضيه اينكه بكى كانون آسيب ديده درمغز كه سلولهاى آن مرده است ويا فاقد فعاليت عصبى شده اند جكونه باعث بروز جنين بيمارى ميشود. خالى از اشكال نبوده و بلين سبب ميياشد كه تاكنون فرضيه اي كه جامع و موردقبول همكان باتد تنظيم نكرديده است (180:

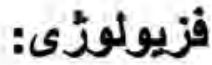

از جهت فيزيويتالوزى حمله صرعى را ميتوان تظاهرات غير عادى فعاليت مغز دانست كه بطور متناوب عارض ميشود اعم از اينكه محل تاثير عامل اصلى در مخ ويا درخارج آن باشد ـ به عبارت ديكر صرع را ميتوان يكى حالت بي نظى در فعاليت الكترونكى وفزيكى وشيميايى خارج شدن انرزى اضافى سلولهاى مغز دانست ـ درسالهاى اخير بشَر

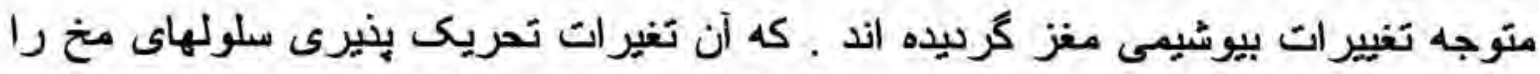
سبب شده وممكن است به شكل موضعى يا عمومى تظاهر ات آن جلوه كرشئود.

از جهت موضع ومحل مغز كه اختلال آن باعت تظاهر ات صر عى ميشود بررسى هاى زياد صورت كرفته است. ر مر مرع علامنى كه با علانم شخص محل آسيب 
ديده توام باشد تشخيص آسان است ( صرع تاميورال - صرع قمحلوى - صرع عاريتال ) ولى درصرع هاى ديكر ، زمانى شكنج هاى منطقه حركنى قشر مخ ( شكنج جبهه صاعد )

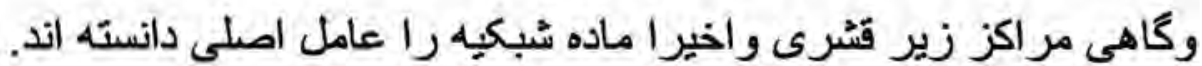

به عقيده بعضى صاحب نظران نسج مخ ، مولد حمله صرعى مياش ولى اين برسش جا دارد كه يافت يكاتريس كه جانشين سلولهاى مرده مخ شده جيونه ميتواند منشاء الثرى وانرزىى براى اختلال درعمل مغزى باشد ؟ بلكه ميتوان كفت كه سلولهاى سالم يا نيمه سالم مجاور بافت سيكاتريس هستتد كه مبدا ومنشاء براى ايجاد اختلال عمل مخ به شمار ميروند. آنجه مسلم است اين است كه عارضه قابليت تحريك نورونهاى مغزى بعلل نامعلوم افزايش ياقته اواين نوع واكتش مخ را سبب ميشود.

متذكر ميشويم كه استانه تحريك بنيرى نورونهاى افراد متفاوت بوده و از روى تجربه به تزريق صد ميلى كرام كار ديازول يعنى اشخاص به حمله هاى تشنجى مبتّلا ميكردند وحال آنكه ديكران به هيجيَونه عكس العمل دجار نميشوند.

هجنين ميدانيم كه عارضه تب نزد بعضى از كودكان موجه حمله صرع ميشود درحاليكه بساكونكان ديكر با تبهاى زياد هيجحُّنه تُّنجى از خود بروز نميدهد. (5: 155)

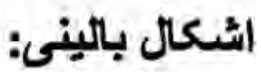

حمله صرع ممكن است به شكل حمله بزرگ يا حمله كوجى يا صرع صدغى يا بيسكو مونور ويا بشكل معادلات صرعى عرض اندام كند.

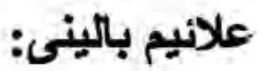

علانيم بالينى ضايعات منطقه صدعى بسه حصه تقسيم ميكر دد.

1. اختلالات حواسى وساتسوريل - ويسيكوسانسوريل)

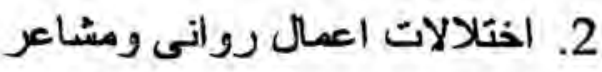


الف : اختلالات حواسى : نسبتا فراوان بوده وعبارتند ازتو همات شنوانى بويايیى توهمات

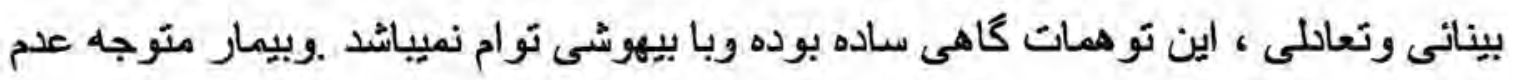

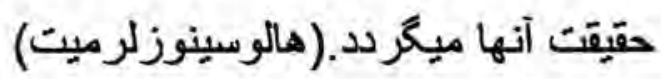

ولى كاهى به اندازه شديد است كه نه تنها بيمار را مثوجه خود ميسازد بلكه سبب بروز يكى

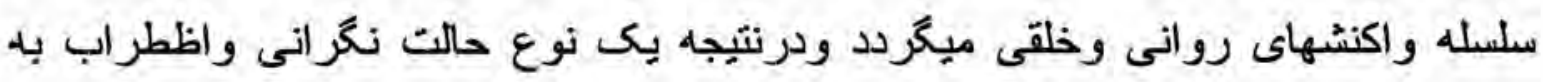
بيمار ست ميدهد.

ضمنا متذكر ميشويم كه او هام بويانى وشنوانى ارزثنى موضعى بيشترى دارند.

ب : اختلالات اعمال روانى : اين كُونه اختلالات را زاكسون بنام حالت رويا ( ريمى تيست) ناميده است ـ آزوالين در برسى هاى بعدى خود اين دسته اختلالات را جنين شرح

1. اختلال تكلم: درضايعه تاميور ال جب ممكن است اختلال كفتار عارض كردد و لى دراين عارضه بنايستى منتظر آفازى معمولى بود بلكه اختلالات تكلم بصورت منفى دئى ررضمن حمله بروز ميكند بدين ترتيب كه وقتى با بيمار ضمن حمله صحبت بنمايند

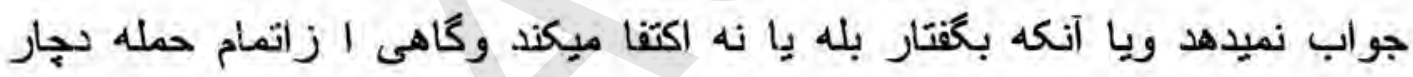
رُاركون آفازى بيا بارا آفازى ميكردد.

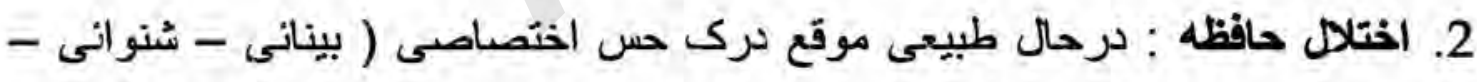

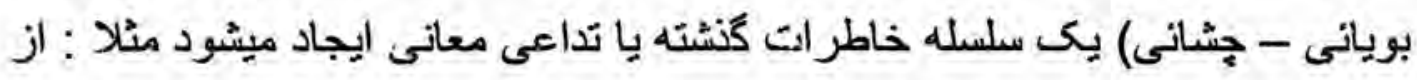
بوى بنفشه خاطره بهارى واز لينن عكس سركنشت دوسنى بخاطر خطور ميكند ولى مرصرع صدعى مرك حس مذكور معمولا با اجبار واضطراب توام ميشود .

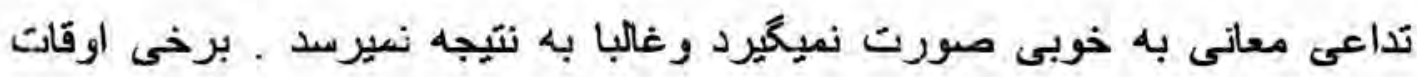
درجريان حمله بيمارى

Halluciantion -1

Alajonanine -2 


\section{Paraphasie -3}

اشخاص يا اشيانى كه براى بيمار عادى بوده بشكل ناشناس با غريبه جلوه كر ميُوند. كاهى اوقات ضمن حمله خاطرات كودكى با حالت اضطراب وشكفتى تظاهر ميكند (اكمنزى) زمانى كه سلسله خاطرات بى در بـى از مغز بيمار عبور ميكند( خاطرات بانور اميك ويلسون ) كه بيمار درحال طبيعى نميتو اند بشرح بيردازد.

بلاخره زمانى حالت رويا به بيمار دست ميدهد دراين صورت عوامل حافظه وتداعى معانى كاهى مخلوط زمانى به يكليكر مبدل شد وهنكامى هم جنان بهم بيوستكى يبدا ميكند كه حالتى شبيه به رويا وخوابديدن به بيمار ستى ميدهد

3. اختلالات عاطفه : اختلالات عاطفه درحمله اين ناحيه فراوان است واغلب جنبه وسو اس ودرعين حال زجر دهنده ونار احت كتنده بوجود ميارود.

كاهى اين اختلالات بس از بيدايش يك مقدمه (اورا) مردستكاه نباتى شُروع ميُود. (5: $(170$

\section{صرع (ميركى)}

وقتى بإى تعريف صرع درميان ميايد همه از خود سوال مينمايند كه آيا ميرگى يك مرض است يه بِى عزض: عرض آنست كه درجريان يك مرض كه سبب معين ميداشته باشد بحيث يكى از تظاهرات آن خود را نمايان ميسازد وجون صرع هم درثناى امراض مختلفه بظهور رسيده ميتو اند لهذا بحيث يك عرض مرض بشمار ميرود.

اما يك شكل آن موجود است كه دزان هيج يك سبب ويا لليل براى بيدايش حملات سراغ نميكيرد كهد به آن ميركى اساسى نام داده اند ويكى موجود مرض مستل مينو اند تلقى كردد.

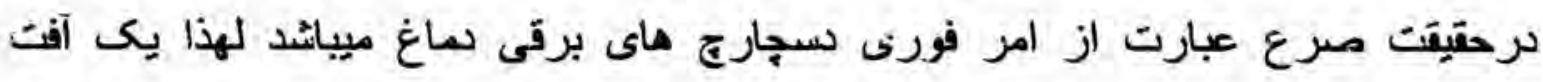

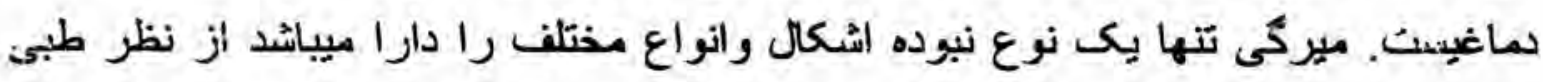

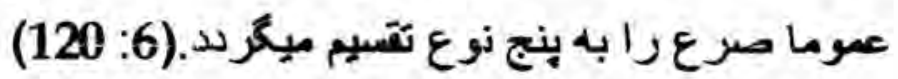


معمولا كيفيات مقدماتى موسوم به (اورا) از جند دقَّهَ تا جند سناعت بيش و و يا بلافاصله

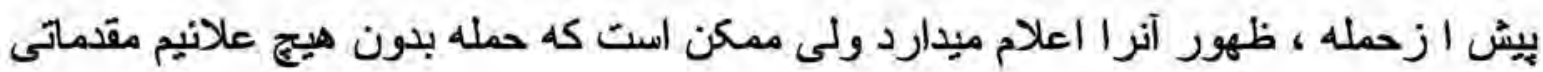
وبه طور ناكهانى بروز كند.

(اورا) - برحسب اينكه علائم مقدماتى حركتى يا حسى يا فكرى بيا نباتى و احشانى باشد آنر ا حركتى ، حسى ، فكرى ويا احشانى مينامند.

(اورا حركتى ) اين (اورا) عبارت از بيدايّ حركاتى درست ويا دريا و يا درقسمتى از اندام ويا ررصورث ميباشدكاهى اوقات يك نوع تكانهاى عمومى ويا زبنهاى طبيعى ويا اعمال كوناكون از قبيل عمل مزمزه وملج ملج كردن ، تجسس ويا جمع كرن ويا دويدن ويا رست هايمال كردن جيزى (اورا) راتشكيل ميذهد.

(اورا) - عبارتست ا زيبدايش درد يا خواب رفتخى يا سستى در دست ويا دريا ويا درصورت احساس وزش باد درصورت يا تنه ويا احساس سوزش وياكيفيت يار استيزى كه تعداد وانواع آنان بى اندازه متغير ميبانُد.

(اوراى فكرى ) عبارتست ا زاحساس فر اموشى ، يبدايش فكر ثابت يا جند لحظه هذيان ويا تحريكات مانى شكل ويا ترس ، وحشت وغصهه ، ويا مستولى شدن فكر مرگ فورى ويا يبدايش تو همات ذهنى كه درمنطقه بينانى وشنوانى به ظهور ميرسد يا ديدن جيزهاى درهم وبرهمى كه نتون كيفيت آنرا بيان نموده ويا آنجه قبلا ديده ويا شنيده شده است دومرتبه ديده ويا شنيده شود ويا تمايل بلا ارادى با نجام دان برخى اعمال عجيب وغريب اوراى احشانى

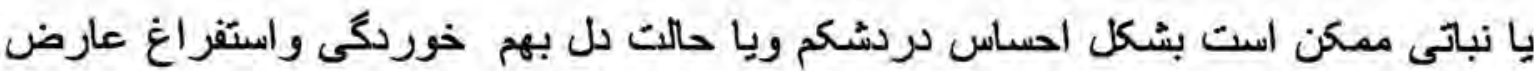

اين حالت نزد بيمار ممكن است هميشه بيك شكل عارض شود ودر اينصورت نشانى بسيار مهم است جه ممكن است بيمار به محض بيدايش آن خور إمهيا سازد واز خطر سقوط نجات يابد. (1): 230) 


$$
\begin{aligned}
& \text { 1. حمله بزرگ صرع } \\
& \text { 2. حمله كوجى صرع } \\
& \text { 3. صرع هاى توضيعى يا قَسىى }
\end{aligned}
$$

4. صرع هاى حركى مختلف كه از منطقه تحت قَشرى ميآيند

$$
\text { 5. صرع هاى روحى حركى ملى هرى }
$$

براى اينكه خو انندكان كر امى معلومات كوجه ومفيدى درزمينه داشته باشند لازم مى بينيم هرشكل آنر ا جداكانه تشريح نمانيم.

\section{Grandmal 1 . حمله بزرگ صرع}

تعت اين طبقه بندى مينوان از نوع بزرى يا Grandmal نام برد كه از منداول ترين اشكال صرع ميباشد كه تقربيا 60 فيصد مريضان به آن مصاب ميياشد . اين نوع بيمارى

$$
\text { دار اق بنج مرحله ميياشد. }
$$

1. مرحله اول : تمام مريضان مرحله اول را نميداشته باشند اين مرحله جندين روز قبل يا يكى ساعت قبل از حمله آغاز ميشود ويا ازدياد ، تخريش ، بيقرارى ، كيجى ، سردردى ويا احساس غمكينى مشخص ميكردد. 2. مرحله دوم : اين مرحله نيز ممكن نزد برخى افراد ديده شُود كه جند لحظه قبل از جمله واقع شده وبراى جند ثانيه ادامه يابد كه قبلا از آن به عنوان علايم هشدار

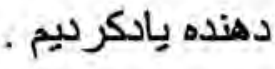
3. مرحله سوم : آغاز حمله اصلى ميباشد كه حالت شعورى يا آكاهى تغير خورده به روى اتاق مى افتد كه كاهى حق فرياد بلن توام ميياشد ممكن بيمار در اثر سقوط خودرا زخمى سازد، يا ممكن دراب ويا آتش بى افتد بازو ها و باهاى وىى كش شده ، سرش به طرف عقب قات كَريده ، تنفس قطع گرديده ، لبهايش كبود ميكردد ورنكش زرد ميكردد اين مرحله براى نيم شقيقه داوم ميكند. 
4. مرطه جهارم : براى تأيم تا دو دقيقه داوم ميكن بعد از آنكه هوا دوباره داخل

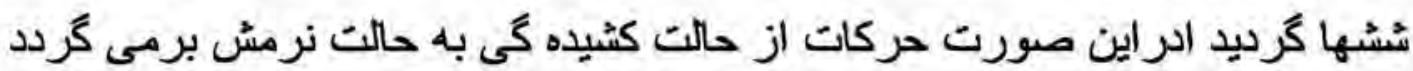
كه با تكان خوردن داوم مى يابد ـ دراين حالت عضلات مريض لرزشى نموده

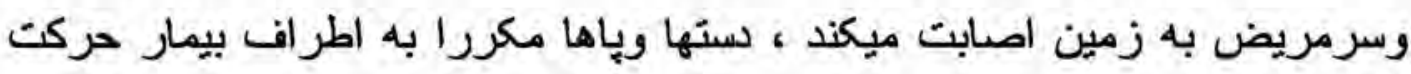
ميكند لاشه هاى باز وبسته كرديده از دهن مريض كف خارج ميشود وغالبا بيمار زبان خودر ا كزيده دهنش خون آلود ميكردد . كاهى بيمار در اثثى حمله اربرار خودرا

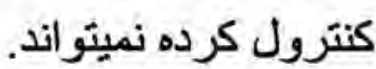
5. مرحله بنجم : مريض مانتد حالت عادى خواب مياياتد اختلالات توقف كرده ، بيمار ممكن است براى جند ساعت بخوابد بعضى از مريضان به زودى بعد از آنكه حمله

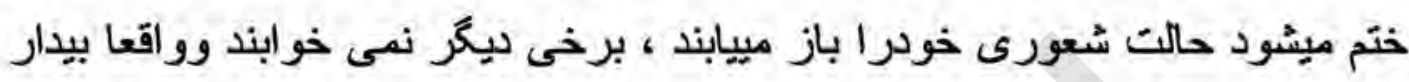

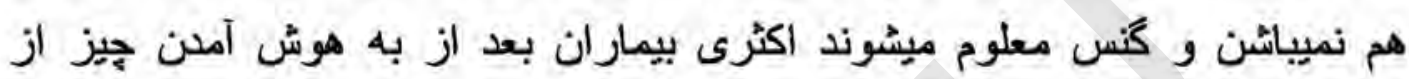
جريان حمله به ياد نميداشته باتشد.

نوعى دكير از حملات بزرگ حالتى است كه status epileptics ناميده ميشود دراين نوع بيمار بيدار نشده بدون فرصت دربين دو حمله يا بيشتر از آن تا مريض حالت شعورى برى

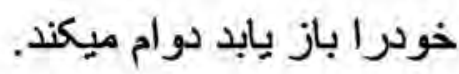

كرجه حمله صرع خيلى زجر دهنده است ولى به صورت عادى باعث صدمه جسمى

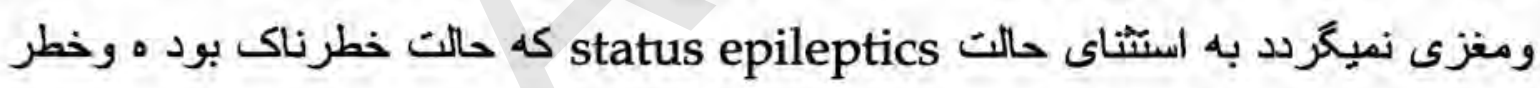

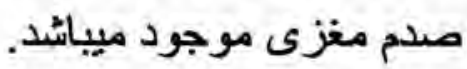

مريضانى كه به نوع بزرى وحمله عمومى مصاب اند ، اكثرى اوقات به خود صنمه

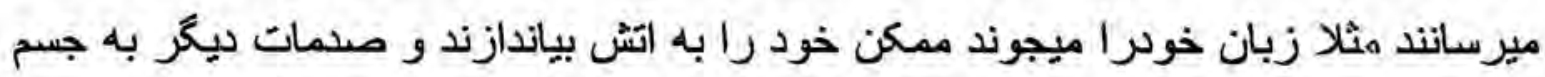
شان وارد كردد. بعضى اوقات به زمين افتادن مريض خصوصا از ارتفاعاتا بلن ممكن صنمات جبران ناينير وخطرناك را به بيمار وارد نمايد . 


\section{نوع كوجَ يا Patetmal:}

نوع كوجك ثيز از نوع حملات عمومى است اينحمله به صورت عدم حضور ناكهانى ذهن نسبت به محيط دربيمار بوجود مى آيد . حمله به شكل است كه نكاه مريض به به حالت خيره

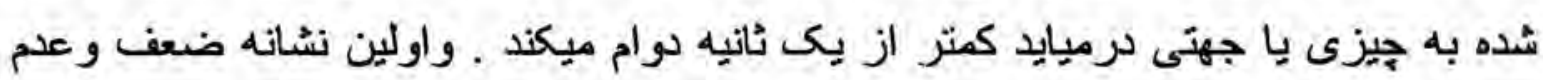

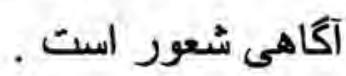

كاهى فعاليت برقى مريك ناحيه مغز شروع وختم شده بعدا به تمام مغز انتقال ميابد اين

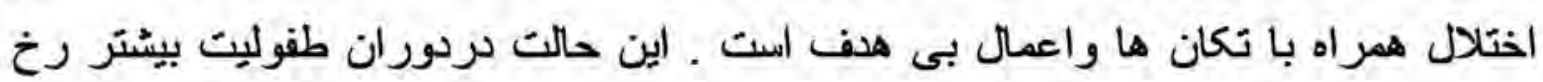

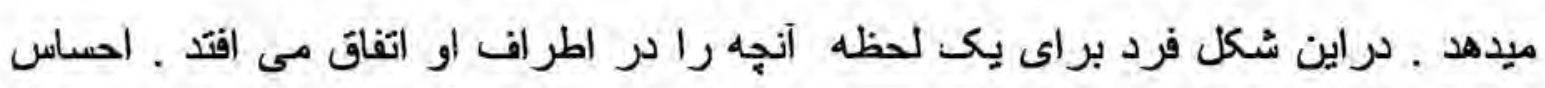

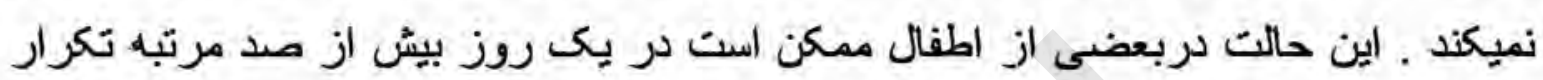

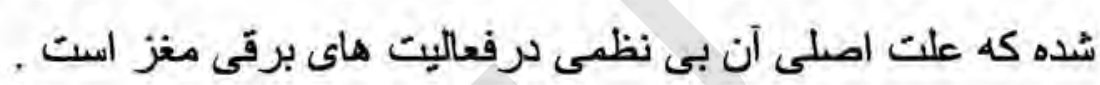

\section{نوع جكسونين Jaksonin}

اختلالى است كه دريك قسمت از بدن معمولا بازوها وياها به مشاهده ميرسد دراين حالك

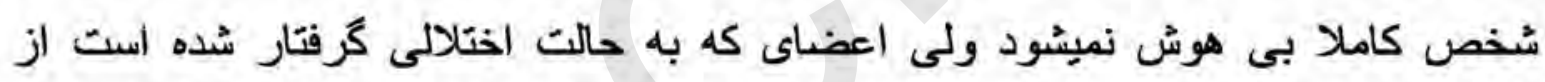

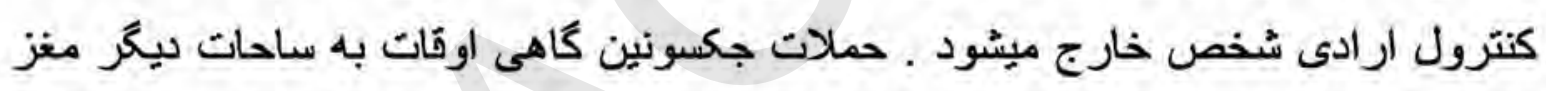

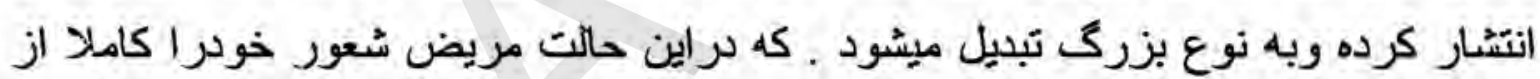
دست ميدهد.

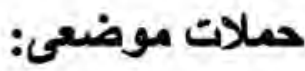

اشكال ديكر صرع وجود دارد كه شخص دران ضياع شعور نداشتَه مكر حالت شعورى

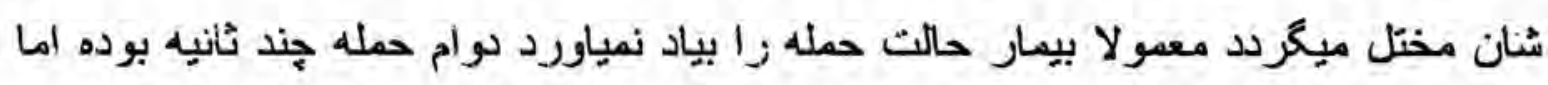

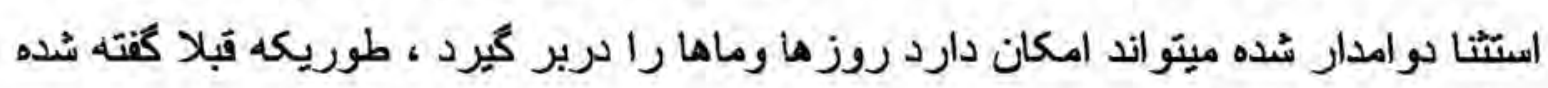
بيمار بعد از. عادى شدن حالت شعورى جيزى أز جريان حمله به بياد نميداشته بانشد. 
زير عنوان حملات موضعى ميتوان اشكال ذيل را نام برد.

\section{حمله صرع روانى - حركى:}

خصوصيات اين نوع صرع را به شُكل كامل بيان كرن مشكل است، زيرا علايم آن نظر به اشخاص فرق ميكند جنانجه بصورت عمومى در شعور بعضى اقراد نخست اختلال رخخ ميدهد دراين حالت شخص باوجوديكه مصروف كار است ويا صحبث ميكنمد ، كم ويا بيش به حالت شعورى قراردارد ، ولى ممكن است از جاى خود برخيزد ، به قدم زدن بيردازد ، ويا ممكن ندانهايش را بجود ويا لبهايش را از تن بيرون كند تمام اين حالت بصورت نيمه شعورى صورت ميكيرد همجنان ممكن است ازبيمار سوالاتى به عمل آيد كه به شكل از اشكال جواب دهد ، ولى براى شنونده جواباتش مغشوس معلوم ميكردد . دراين حالت مريض ممكن است فواصل زيادى را طى كند ، بعد از آنكه به حالت شعورى خود باز

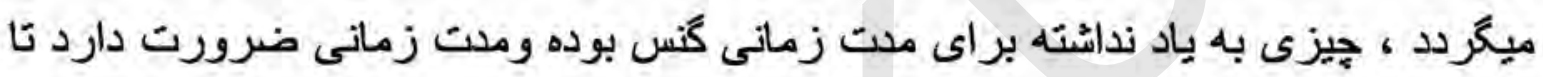
به درستى بداند كه دركجا قراردارد بعضى از اين اشخاص بعد از به هوش آمدن ممكن بردي

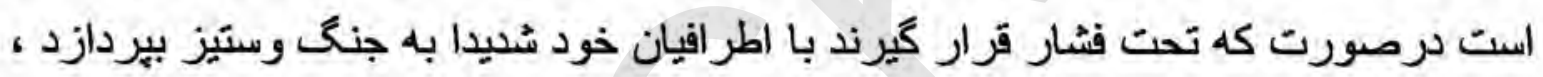

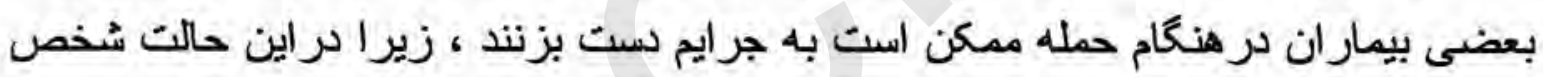
درحالت نيمه شعورى قرار داشته و آنجه انجام ميدهد آكاهى كامل نداشته باشد.

براى اين نوع مريضان بايد تدابير لازم اتخاذ كردد تا از وقوع مسايل فوف جلوكيرى به عمل آيد وهم از آنها مر اقبت به عمل آيد تا به خود وبيكران صدمه نرسانند.

بعضى اوقات اطفالى كه مشكلات سلوكى دارند ، ممكن است به صرع روانى كرفتار باشند

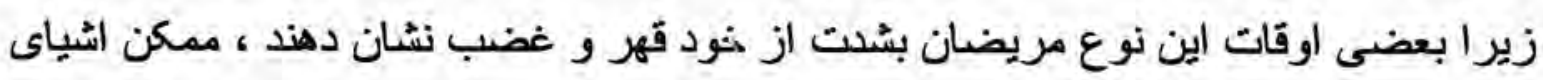

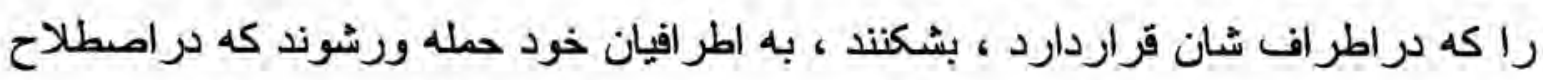
عامه اين نوع اطفال بد مزاج يا بداخلاق ناميده ميشوند اما اين اطفال بعد از رفع شدن حمله ر اوقات نيكر رفتار عادى ونورمال دارند و حركات نيكو از خود نشان ميدهند براينجا بايد تنكر داد كه همه اطفالى كه مشكلات رفتارى دارند از صر وعر رواتى متاخر نميباشند بلكه 
عده انكثت شمار را ميتو ان به وسيله آله (EEG) تشّخيص كرد ـ اين نوع حمله براى اولين

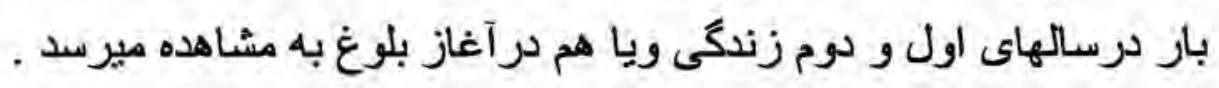
درساير اشكال صرع از نوع حملات موضعى خصوصيات نيل ديده ميشود. - بيمار سر وجشهاى خود را به يكى طرف دور داده بازوى عين طرف را بلند

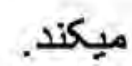
- جهره بيمار تغير ميكند ويك دست آن تكان ميخورد نكان ها درقسمت هاى ديكرى بدن نيز ممكن به وجود آيد.

- بيمار احساس عجيب دريك قسمت بدن ميكند( ردد، سوزنك زن بن يا كرختى)

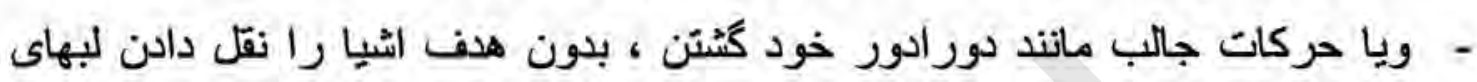

$$
\text { خودرا مكيدن }
$$

حمله براى مدت زمان كوتاه ادامه مى يابد ، ممكن بيمار برا ى جند لحظه قبل از حمله

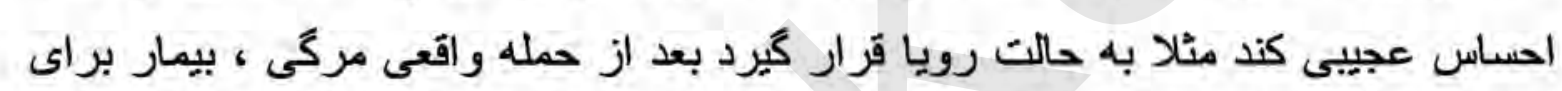

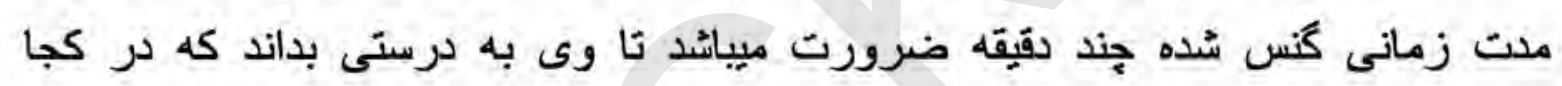

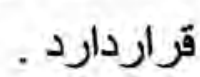

ر راطفال انواع مخصوص صرع ديده ميشود ، مثيلا تكانهاى كوتاه مدت دربرخى از عضلات ، بعدا سقوط آنى طفل به زمين ويا حملات خيلى كوتاه مدت كه فكر ميشونطفل درمحل حاصر نباشد.

\section{فزيولوثُى وفارمكالمُّى صرع:}

بيركر Beger درسال 1929 نثان داد كه تغير خصوصيات برقى مغز را ميتوان به وسيله

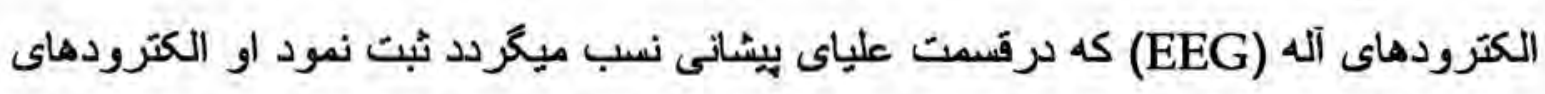

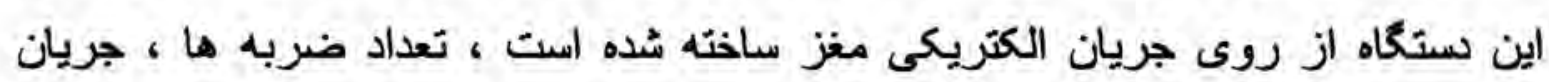

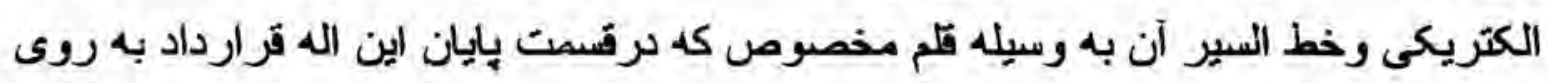
كاغذى مخصوص رسم ميشود. 
امواج الكتريكى مغز هريكى ا ز موجودات (انستان وحيوان) برحسب فعاليت هاى مغزى هريك متفاوت است ـ همجنان امواج الكثريكى دربين انسانها از همديكر متفاوت است . . امواج الكتريكى مغز درموارد عادى وغير عادى حالت خشم وهيجان ويا آرامش به بكى نسبت معين تفاوت دارد ـ. دربيمارى هاى عصبى وروانى اين خطوط وضعيت نامنظم دارد ، طوريكه درابتدا انتها ووسط اين امواج دايره هاو اتحنا هاى بسيار را تشكيل ميدهد. ريكارد الكترو انسفالوكراف اشخاصى كه به انواع صرع كرفتار باشد از يك ديكر فرق

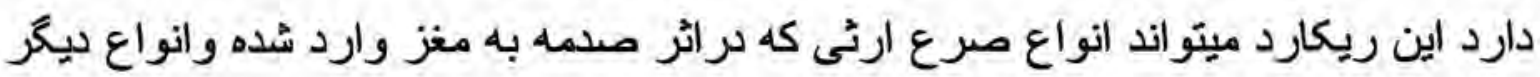

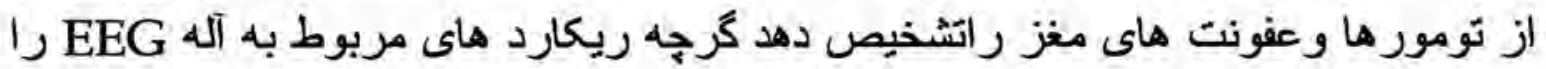
نميتوان بى عيب قلمداد كرد ولى به وضاحث كفته ميتو انيم كه نتايج EEG درتشخيص علايم كلنيكى صرع 60 فيصد صحت دارد.

درشكل ذيل بعضى از انواع الكتريكى مغز شخص مصاب به صرع نشان داده شده است.

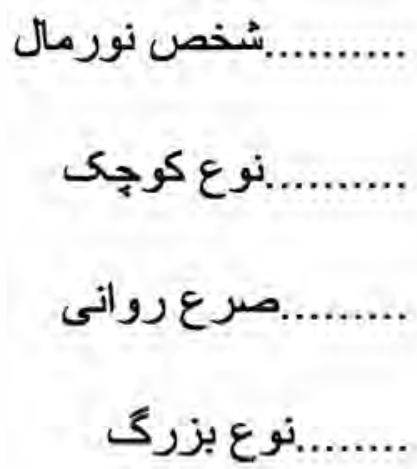
شو اهد به دست آمده به وسيله ثبت أمواج الكثريكى مغز نشان ميدهد كه نمونه هاى سجارع شده غير عادى تشنجات اعصاب نتيجه فعاليث غير عادى مغز است ناحيه سجارع شده ممكن أست ساحه محدود را احتوا كند ويا هم تمام قشر دماغ را دربر كيرد امكان دارد از يك،، نقطه مغز شروع شود وبه نقاط ديگر سرايت كند طوريكه قبلا كفيثم ، اكر سرعت تتفس از حالت عادى سريعتر شود و آكسيجن بيشتر از حالت نورمال به شخص برسد درآن صورت EEG امواج غير عادى را درمغز شخص مصاب به صرع نشان ميدهد ـ اين وضع هم ربعضى حالات EEG همراه با روشهاى تحقيق كرناكون نيرولوزيكى نشان ميدمد كه ساحه معين مرمغز وجود دارد كه إز آنجا اختلالات صرع نشات ميكند . هركاه 
اين ساحه درساحات قابل جراحى مغز موقَعيت داشته باشد جراح ميتوان اين ساحه را از بين بيرد ومريض را از اختلالات نجات دهد.

دواهاى مختلف براى معالجه صرع وجود دارد ، ادويه هاى كه بيمارى صرع را علاج ميكثد انواع واقسام آن بايد بعد از تشخيص توسط داكتر تعين شود ، زيرا دربرخى بيماران صرع بعضى ادويه هاى تاثير مثبت و دربرخى ديكر تاثير منفى دارد.بيده شده است كهات تطبيق طو لانى (برمايسـBormides) بالاى بعضى مريضان حرع سبب تخريب بعضى خصوصبيات ذهنى شده است رحاليكه تحقيقات سيكر در زمينه نشان مبدهد كه تخريب ذهنى درمريضان كه از ادويه برمايد استفاده نكرده بودند نيزيكسان بوده است . دراثر بيشرفتهاى كه درفارمكالوزى صرع به وجود آمده است امروز ادويه هاى موثر براى بيمار ان صرع توصيه ميّود كه تأثيرات جانبى كمثر دارد.

\section{صرع هاى قشمى:}

يعنى حمله صر ع يك قسمت فعاليت با اعضاى سيستم عصبى را علاقمند مى باش دراين جوكات صرع به اصول مى آيد. صرع حسى ( حس مرمر سوزنك زدن كرمى يا سردى ريكى قطعه يا قسمت جسم بيدا ميشود) صر ع حواسى ( ديدن رنك هاى ، شنيدن صداهاى كه اصلا وجود خارجى نداند ـ احساس بوى و ذايق ) شامل ميياشد.

بعضى حملات دردناك شكم ، استفراغ ، درد إيانديسى احساس فشردگى درسينه ، دردهاى ناحيه قلبى ، سردردى ها خواب را درحاليكه بيگر براى شان وجود ندارد ومدت بروز وزمان بوجود آمدن شان كوتاه باش به صر هرع قسمى ارئباط داده مينو انيم .

\section{حمله تشنجى:}

حمله تشُنجى حقيتاً وبلا مقدمه رراثر خستكى ويا خورن غذاى بد عارض ميُّود و نزد

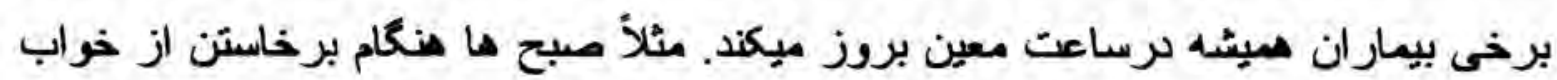


ويا موقع خوابين حمله تشنجى بسا اوقا بطور نامنظم عارض ميشود و نزد زنها مخصوصـا هنخام قاعده شدت ميابد

بيش از بروز حمله بيمار درائر تشنج عضلات حنجره وقفسه صدرى فربادى ميكند (اورا) او يك بارجه بزمين ميافتد بدون اينكه ررصدد حفظ خويش بر آيد.

به همين جهت غالبا سرودست وباى او مجروع ميشود. وجود اين زخم ها براى تشخيص بيمارى كمى كرده واز جهت طب قانونى اهميتى بسزا دارد.

وقتى بيمار بزمين ميافتد اول به انقباضات وريد ها و سيّ به انقباظات تكانى دجار ميكردد دراثر انقباظات ماهيجه هاى قفا سربه عقب ويا بيك طرف منحرف ميشود ودراثر انقباض برئ ماهيجه هاى ارواره هافكى ها بهم جسبيده ودندانها به يكنيكر فشار وارد مياورند و غالبا زبان ميان دو آرواره ميماند وزخمى شده ياد ميكند وهم جنين نيز ممكن است زخمى شوند

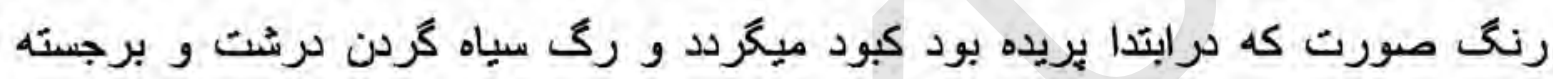
ميشوند اين امر به علت اين است كه انقباض ماهيجه هاى سينه مانع تنفس ميكردد وى نبايد ازخفه شدن بيم وهراس داشت جه اين انقباض فور ابرطرف ميشود ومرحله تشنجات تكانى فر اميربد ودست ويا را به تكانهاى شديد دجار ميسازد وماهيجه هاي قضا را منقبض ساخته سر را به عقب ميكند ودرماهيجه هاى سرو ناحيه قطنى حركاتى بروز ميكند ـ. غالبا سرو

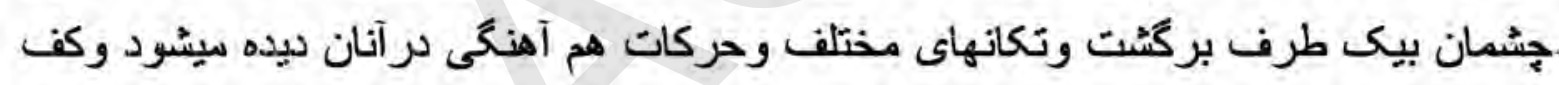

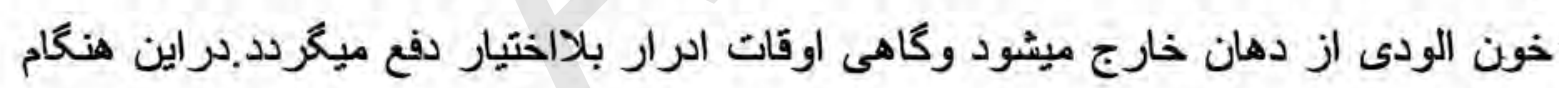

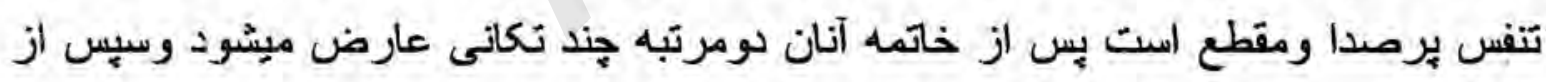
آن بيمار بخواب رفته نفس بلند ميكثد ورنى صورت او ميّر د دراين حالت تمام ماهيجه

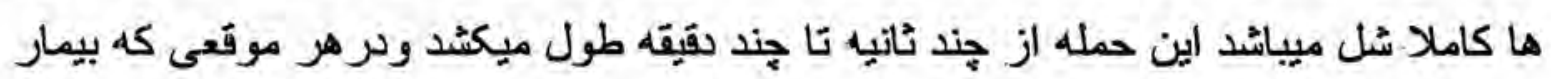

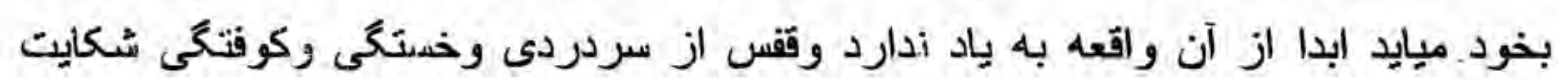
مينمايد.

خموصيات حمله نزد طفل وجوان مشابه أست وممكن است كه رخخاتمه حمله كريه به ملنل سست دهد . بهت نزد طفل سست دهد. بهت نزد طفل كمتز است ولكه ماتى بوريوزا وخون 
مردكى سبب بى حالى احتقان شديد هنخام تكانها درصورت ودر گردن ممكن است ديده شود اين لكه ها از جهت طب قانونى دار اي اهميت ميياشد.

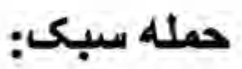

حمله سبك شامل سركيجه ووقفه ميشود غالبا حمله صرعى به شكل خفيف عارض ميكردد ودفعتا رنگ صورت مييرد ونكاه بيمار به يك طرف متوجه وثابت ميشود وكاهى اوقات بلى هاى جشم دجار لرزش شده بيمار بزمين نميافتد ولى آنجه دردست دارد از دست ميافتد و ساكت ميشود وبه سوالات جواب نميدهد وسبِ از جند ثانيه مجدا سر رشته كار با باري صحبث قبلى خود را ميكيرد و غالبا يك حالت كيجى وتغير اخلاق باقى ميماند كه به تدريج برطرف ميشود دربعضى حالات وقفه يا كشفيات خو دبه خود توام ميباشدودراين صورت

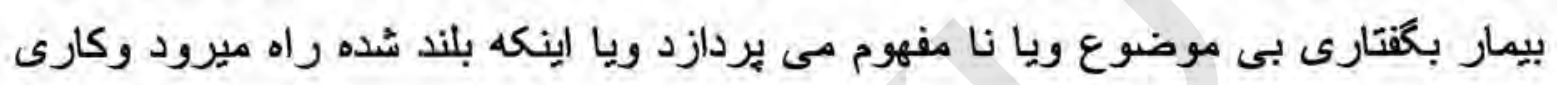

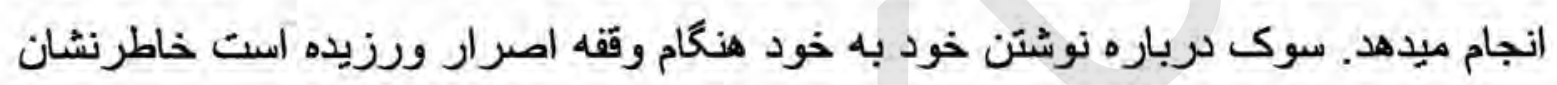

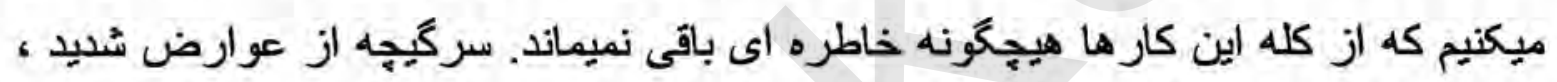

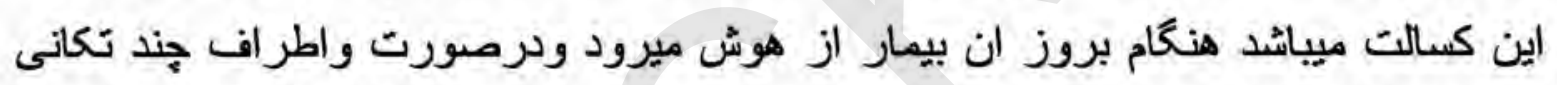
عارض ميشود ودفع ادرار غالبا صورت ميكيرد وتظاهرات خودكار مغز فراوان دست ميت وني ميدهد اين تظاهرات عبارتند از بيدايش رنح بريده گیى درصورت وحركات درست وبيا تكانها ريدن وداد وفرياد ـ اين داد وفرياد ناشى از دردى است كه احساس ميشود ويا از رويا هاى مخصوصى است كه مشاهده ميكردد.

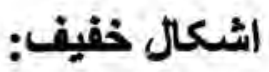

كنشته از دو شكل حمله صرعى كه شرح داده شد ممكن است اين مرض بصورت عوارض خيلى خفيفى در آيد كه برحسب هر بيمار تفاوت ميكند غالبا تشخيص اين عوارض بسيار مشكل ميباشد . خصوصا اينكه دربسا حالات بيمار از خود بيخود نميشود وشاهد كيفياتى كه حس ميكند ميباشد ولى بايد دانست كه بررسى در سابقه بيمار وشاهدات وجزد حمله صرعى مرئ اعم از اينكه شديد يا خفيف باشُد وخصوصيات غير معمولى شكل هائ خفيف باعث 
تشخيص صرعى بودن آن ميكردد واين تشخيص مخصوصا از جهت طب قانون اهميت بسيار دارند.

\section{الف : تظاهرات حركتى:}

تظاهرات حركتى صرعى عبارتند از لرزش و حركات كرده اى شكل وجهت كرن نيم زبانى يا اشكال درتكلم ويا بيدايش انقبضات درماهيجه هاى يكى ناحيه ــ اولين تظاهر

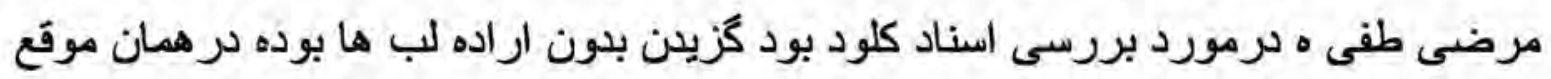

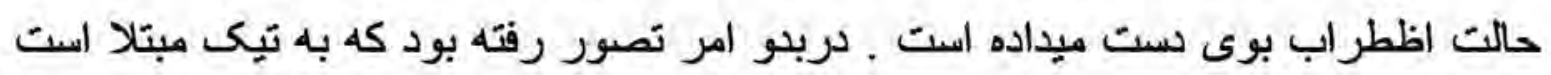
تا آنكه ديده شُد كه لب خودرا طورى دندان كرفته كه باره كرده است.

1- شُت با 2- انكشت كوجى با 3- ميج جا 4- بند لكن 5- زانو 6- شانه 70-آرنج 8-

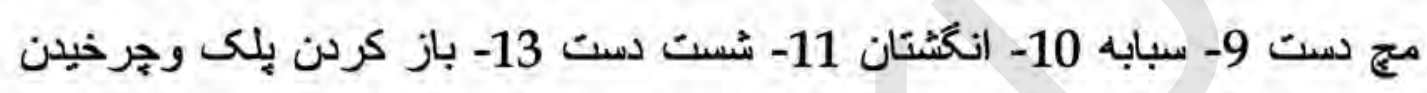
سربطرف مقابل 13- بستن بلك واضعتر رازطرف مقابل 14- انقباض نيمه فوقانى ماهيجه حلقوى لبهاى طرف مقابل 15- بالا بردن لب فوقانى 16- جمع كننده زاويه

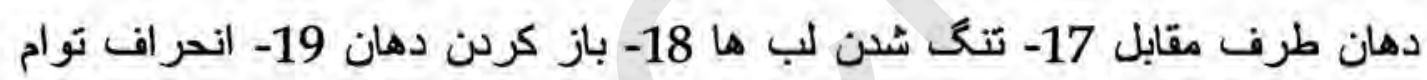

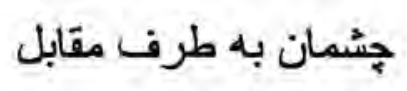

Claude .1

Anxiete .2

Tic .3

Clonque .4

Myoclonic .5

Procursive .6

Crise dautomatisme ambulatoire .7

Fugue .8 
بسيارى از تكانهاى بن وبعضى از ماهيجه تكانهاى از صرع ناشى مياشد علاوه براين حالات بايد كريختن صرعى وكرش صرعى وفراتر صرعى را از تظاهرات حركتى دانسته ونيلا بشرح هريك بطور اختصار مى يُردازيخ.

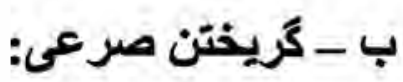

اين حالت نزد كودكان مشاهده ميشود ودراين صورت بيمار بدون علت وسبب آشكار دفعتا مى دود واز موانع عبور ميكند وبه سرعت خود مى افز ايد تا اينكه از حال برود و وناجيار

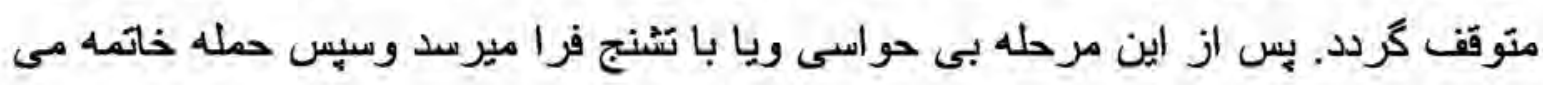

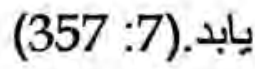

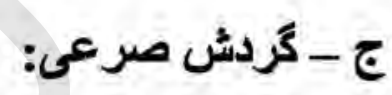

دفتًأ بروز كرده وبيمار در اثر قوه مقاومت نائيرى براه مى افتد وبكرش در همه جا مى دئ

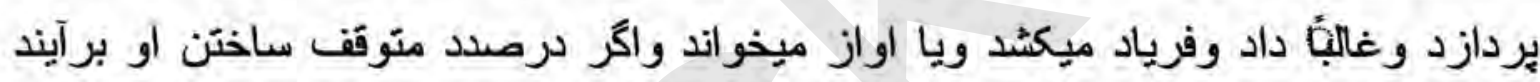

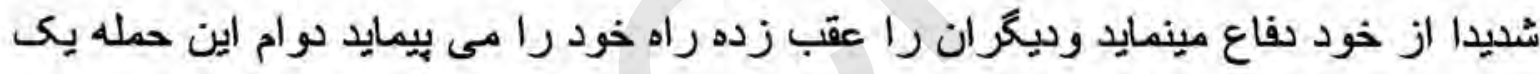

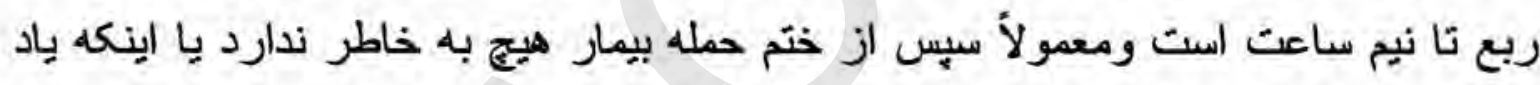

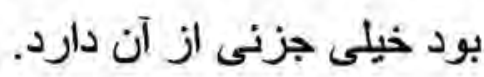

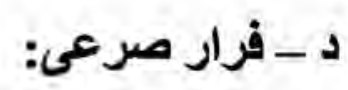

فرار صرعى نادر است رراين حالت بيمار ناكهان حركت نموده راه ميرود و به مسير خود

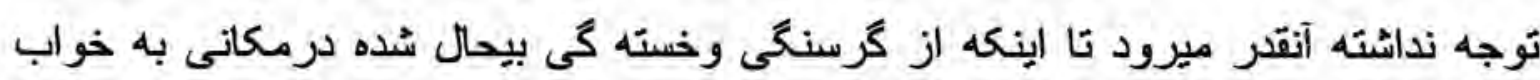

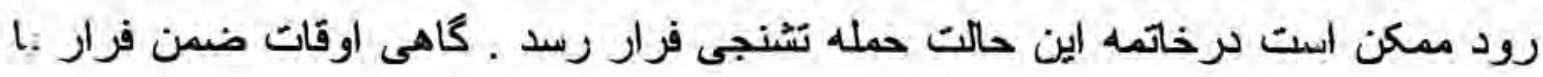
عمال شديد ونزدى ويا مسافرت بطور فرار قاجاق وبا هتى حرمت ميردازد وا زجهت طب قانونى تشخيص دادن مبدا صرعى اين حالات حانز اهميت بسيار است . 


\section{هـ ـ تظاهر ات حسى وحواسى واحشائى}

تظاهرات حسى عبارتند از سردرد ونور الزّى وميكرن وبهم كَرفتحى و حمله خواب وازدياد حس در بعضى نواحى ويبدايش رويا ويارسترى دريكى از اطراف ويا درنيمه صورت اختلالات حواسى شامل كورى موقت وتو همات بينانى ويا شنوانى يا شامعه ميباشد كه غالبا بشكل اورا در ميآيد تظاهرات نباتى عبارتند از بيدايش اختلالات والرزى خفقان مختلف واحساس كرفتخى قلب وتصور توقف قلب وخفتان كانب ودردمعده واسهال ناكهانى

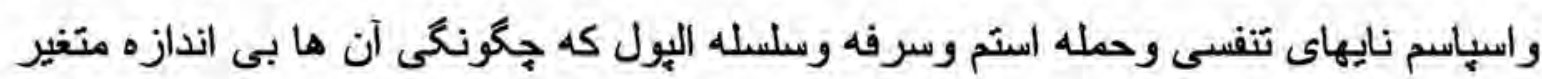
ميياشد.

1- اختلالات روانى : از قبيل تغير شخصت ودو تا شدن آن وكرفتخى و احساس ( اشياى

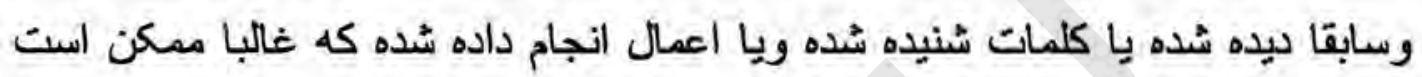

$$
\text { بشكل اورا درآيد. }
$$

2- كيفيات تحريك روانى : طبق تحقيقات دو ثر بانت وييره بعضى حالات تحريكى

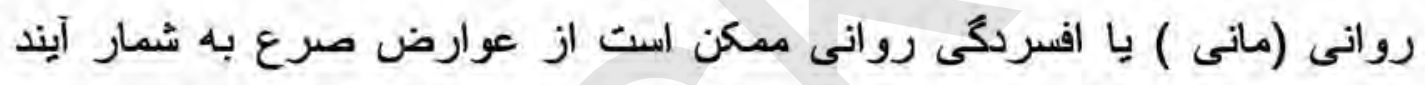

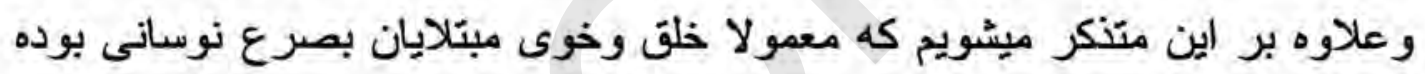

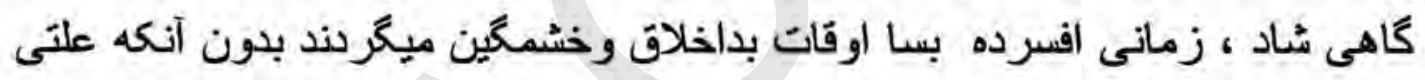

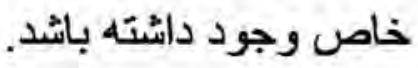
3- اختلال روحى : ممكن است بشكل وسوسه هاى لاشعورى درآيد كه در ان بيمار نه

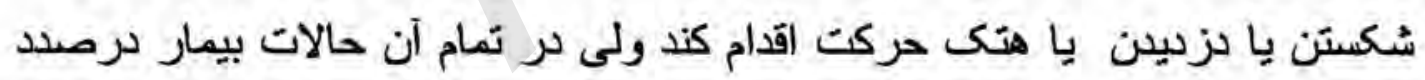
اقدام به فرار ويا مخفى كردن جيز و دزييده شُده برنيامده وبكلى از واقعه ياد ندارد. 4- صرع مددود : بيكى ناحيه يا صرع براوه جاكسن در 1887 برآورده وجاكسن نوعى بردي

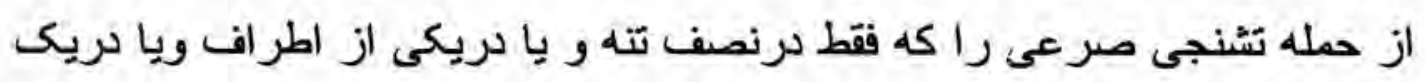

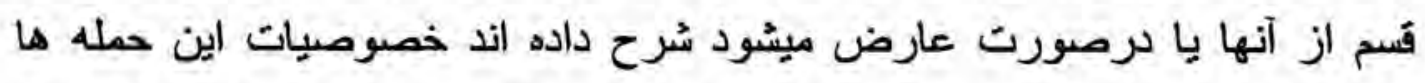

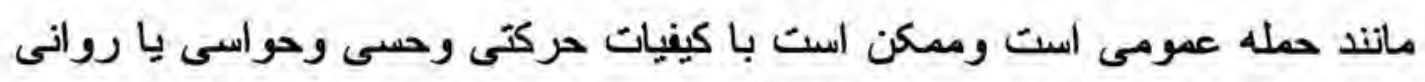

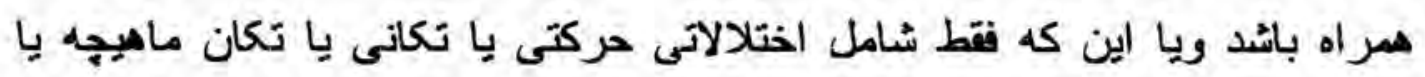

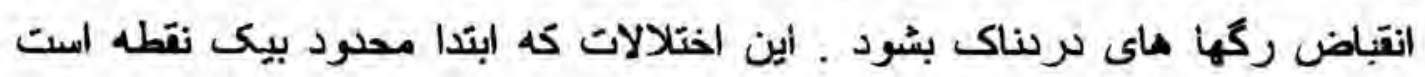


بزودى دست يا بانيم تته ويا صورت را فراميكيرد ودر صورتيكه بر موضوع اولى فثار وارد آورند ويا بازو را نه بندند از حمله جلوكيرى ميشود.

غالبا رصرع بر آوه جاكسن سر بيك طرف منحرف ميشود وجشم ها به طرف راست بيا

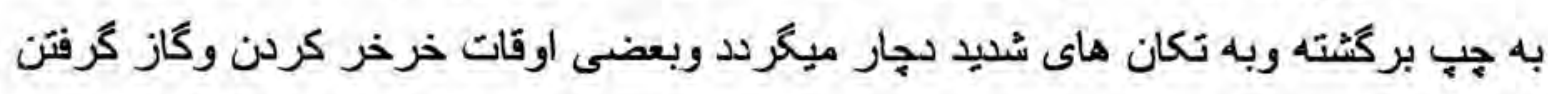

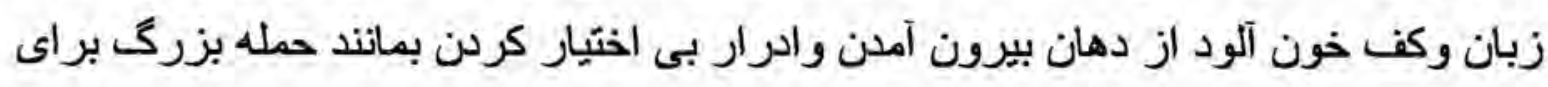
بيمار دست ميدهد.

يكى از بيماراينكه به مراجعه مينمود هنكام صدبت دفعتا از خود بى خود ميشد ورنكً.

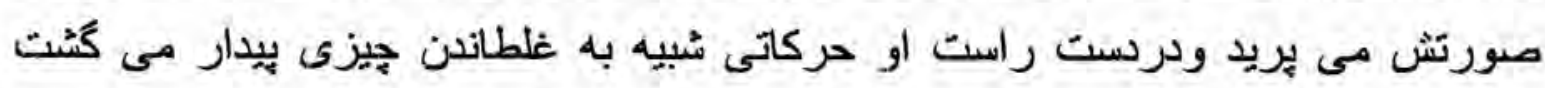

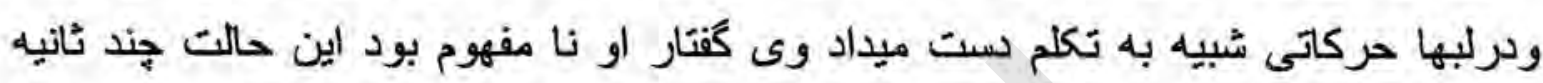
بيشتر دوام نداشت ويس از بخود آمدن جيزى از آن واقعه بخاطر نداشت ماته

دربرخى حالات بيمار از هوش نميرد وفقط درست با سريا با تكانهاى بروز مبكند وممكن

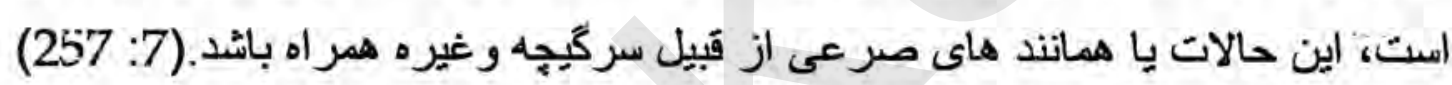

5- صرع صدغى: اولين مرتبه زراكسون ضمن بررسى هاى حالات صرع مخصوبسا.

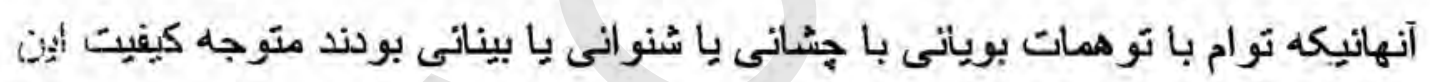

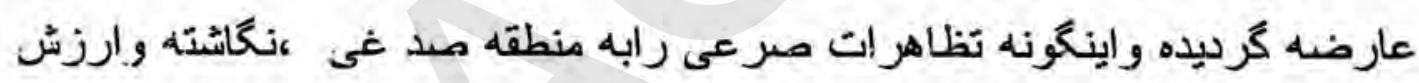
بالينى آنرا با حملات آفازى برابر دانسته است.

كينبه ويلسون : درسال 1928 حالت رويا را مورد برسى قرارداد وخصوصيات آنرا به جهار نوع تقسيم نموده است به شرح نيل ميياشد.

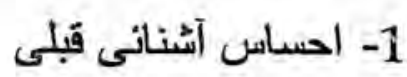

2- احساس شكفتى وتحريك بذيرى

3- خاطره مناظر ودحنه ها بشكل بانور امايا

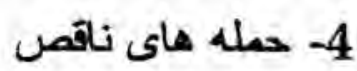


درسال 1924 كه الكترو آنسفالو كرافى توسط هانس بركر موارد استفاده دانش اعصاب قرار كَرفت موضوع حالات مختلف صرع ونمودار الكتريكى مورد توجه واقع شُد .

كيبس - حمله هاى صرع صدغى را بر حسب شكل امواج آن طبقه بندى نمود وخصوصيات حمله هاى بسيكو موتر بس را امواج جهار ضلعى بارنوس مضريس دانست

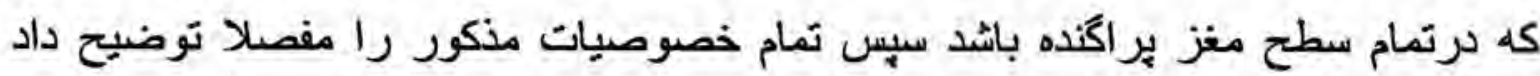

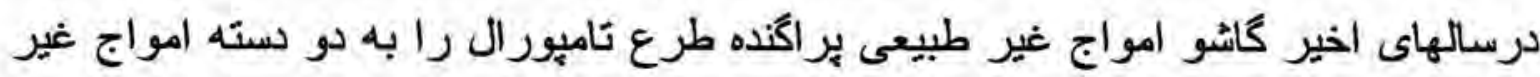
طبييعى بر اكنده وغيره محدود تقسيم نموده .8: 60 (8)

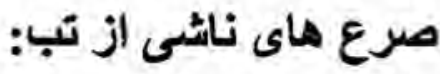

بعضى از شيرخواران وكودكان دراثر تب حملات تشنجى بيداميكند لينوكس lenox تخمين زد كه تقريبا 2 درصد تمام اطفال ، تريكى ا زدوره هاى شيرخواره كى با كودكان يكى يا جند حمله تشنجى ناشى از تب دارند ـ در 20 درصد اين موارد مى توان مشخص نمود كه تب به عنوان عامل مساعد كنده جهت بروز صرع در بيماريست كه قبلا بيمارى مغزى با صرع ايديو باتنيك داشته است. جنين افرادى بدون ارتباط با تب به حملات صرعى خود ادامه خواهند داد در 80 درصد بقيه صرع تنها درحملات تب ظاهر شده وهركز بعداز سبرى شندن اوايل كودكى تكرار نذواهد شد لليل بائين بودن آستانه تحريك بينيرى مغز اطفال معلوم نيست ولى در 50 درصد موارد سابقه بروز صرع ناشى از تب درعضو ديكر فاميل وجود دارد از سابقه بإنه

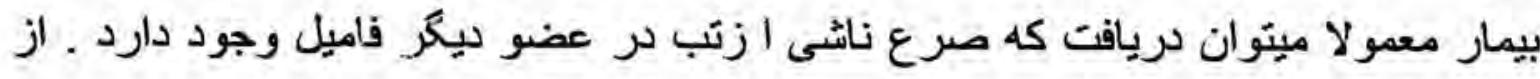
سابقه بيمار معمولا ميتوان مريافت كه صرع ناشى از تب ر سنين بين 1-3 اتفاق افتاده وتنها موارد نادرى زوستر يا ديرتر تا 7-8 سالكى كزارش شده است ـ ممكن است هركونه

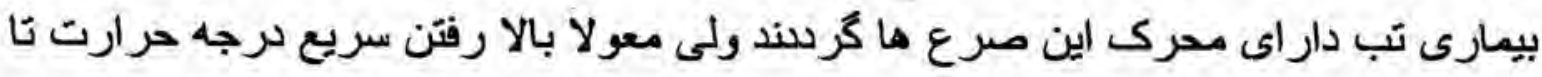

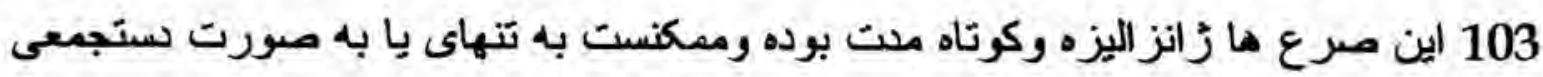

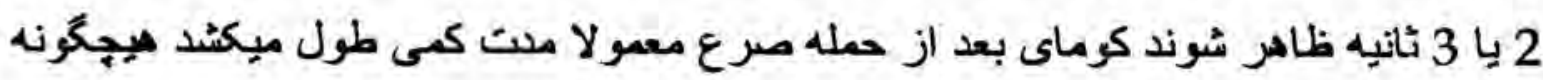


سابقه نشانه هاى فوكال يا مشخص نورولوزيكى نميتو ان بيدا كرد مايع مغزى نخاعى روشن وبدون سلول بوده ومقدار يرونين توتال آن طبيعى است .

الكترو اتسفالو كر اف بطور منتشر غير طييعى بوده و بلافاصله بعد از شروع صر ع درتمام

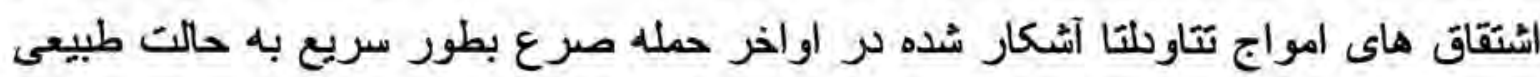

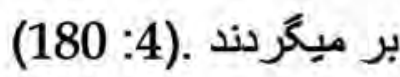

\section{اختلالات ادراك}

اختلالات ادراك اين اختلال كاهى در ابتدا وزمانى درانتهاى حمله عارض ميشود ودراين صورت بيمار بهت زده به نظر ميرسد.

\section{اختلالات بيسكو موتور ونورور تاليف:}

اختلالات دستگاه نباتى اغلب بصورت (اورا) عارض ميشود مانتد درد ناحيه قلب ويا احساس خفكى يا درد وكرفتكى عجيب رمنطقه بالاى شكم (ابیى كاستر ) اين حالات غالباً با اختلالات حركتى و اضطر اب روحى توام ميباُشن.

فعاليت حركتى بشكل خونكار و غالباً منظم ومرتب بوده، درآخر حمله بر بيمار دست ميدهد وبا تاريكى شعور نيز همره ميباتُد يكى از بيماران ما كه خانم جوانى بود در آخر حمله با حالت بهت مرتباً انكثتان شانه وار ودرموهاى خودمييرد همجنين بيمار ديكرى درآخر بحران شروع بخاراندن اشياى مينمود، كه در سترس او بود. كاهى اوقات حركات درعضلات صورت وفى ها وزبان وحلق توام با جرخش سر بطرف مقابل ضايعه مشاهده ميشود كه اين حركات كاهى تنها و زمانى ابتداى يكى حمله عمومى را تشكيل ميدهد. وكاهى هم درجريان حمله فعاليت خود كار شيدي مثل قرار ودوين وتوام با اختلالات روانى وتوهم به بيمار ست ميدهد. واكر فعاليت هاى مذكور جلوخيرى شود باعث تشيديد

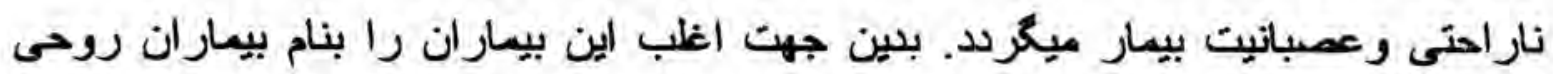
ررتيمارشان مينمايند. 


\section{الكترو آتسفالو گرافى Electroencephalograph:}

در الكترو آنسفالو كر افى صرع صدغى سه سته اختلال مشاهده ميحردد.

1- امواجى بنام امواج نوك دار كه درست درمنطقه ضايعات مشاهده ميشود .

2- امواج غير طبيعى براكنده روى يكى سطح قشر صدغى كه داراى ارزش محلى برائ كمتر ميياشد.

3- سته امواج غير طيبعى بر اكنده روى هردو سطح صدغى ومدل هاى ديكر

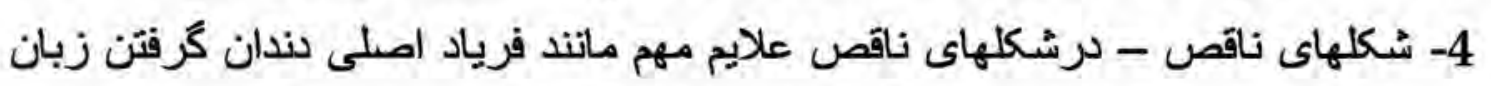

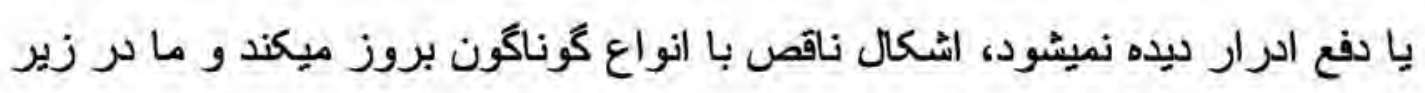

$$
\text { بشرح برخى از آنها ميِيردازيم. }
$$

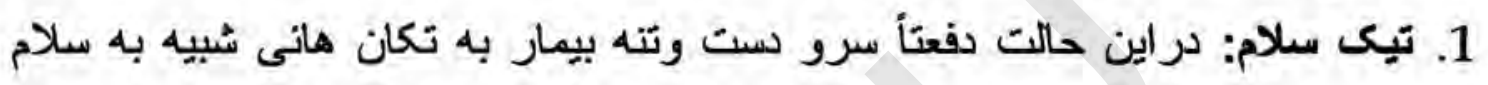

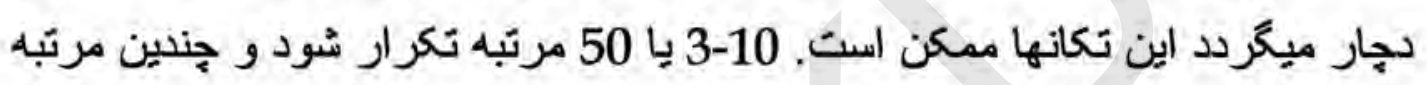

دروز ستك دهد.

2. حله تشنجى ; كه دردست يا باها درلب ها يا رراطر اف بدن بروز كرده و به جاى

$$
\text { ديكر سرايت ميكند. }
$$

3. حله كره : كه درآن دفعتاً تكان هاى شبيه كره دردست ويا بروز ميكند.

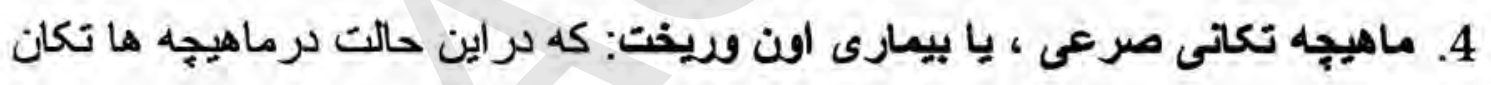

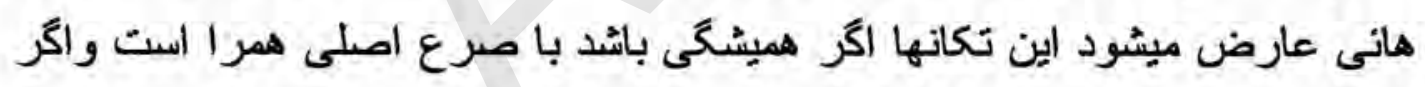
كاه كاه عارض شود غالباً خانو اده كى ميياشد.

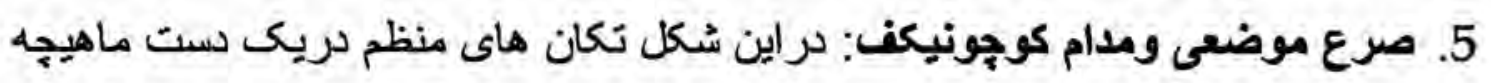

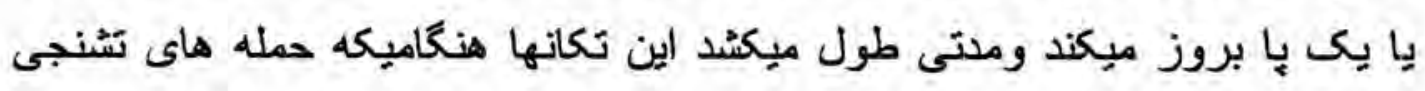
عارض ميشود از بين ميروند. 6. حمله استاتيك در 1924 رامسى هنت: شرح حمله اي را نوشت كه درآن دفعتأ

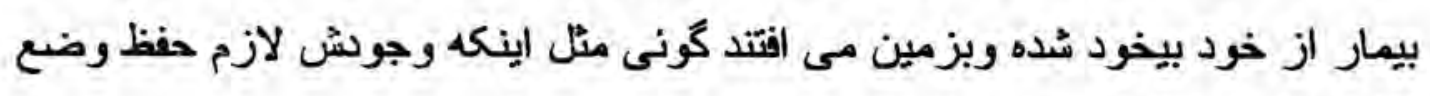
فعلى نزد بيمار از بين ميرود. 7. صرع جسم مخطلط: راين حالت فقط اختلال وجوش ديده ميشود بيمارى كه دجار اين حالت بوده ويا مراجعه مينمود شكليت داشت از اينكه كامى اوقات دفعتاً ماهيجه 
هاى كف بايش سخت ميشود وتا جند ثانيه قار به تكان دان با نميباشد واين حالت با احساس نار احتى همر اه بوده است .

\section{صفات عمومى حمله هاى صرع :}

غالبا بدون علت مشخص ومهمى كيفيات صرعى بروز ميكند ـ برخى اوقات دراثر هيجان واضطراب ويا ترس وخستخى زياد ويا اختلال لوله هاضمه ويا افر اط دراعمال مقاربتى ويا

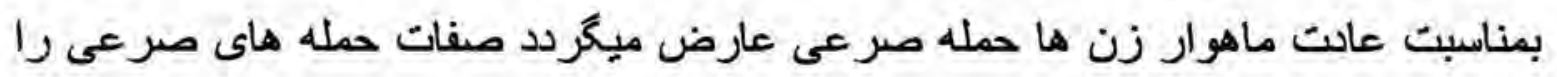
ميتوان بكيفيات فزيكى در موقع بروز حمله وكيفياتيكه بس از حمله دست ميدهد تقسيم نمود.

1- كيفيات فيزيكى: موقعيكه حمله كلى يا جزنى دست ميدهد نشانها زير نزد بيمار

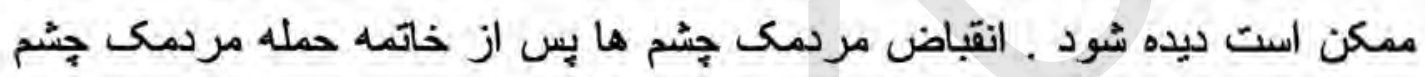

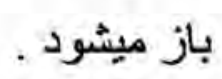

تندى انعكاس هاى ذهنى.

يبدايش يا ينسكى ( بيخود شدن ) تندى ضربان قلب. فثار خون متغير بود و زمانى كم وكاهى زياد ميشود .

2- كيفيات بس از حمله - بس از خاتمه حمله صر عى بيمار مدهوش ميشود ويا اينكه

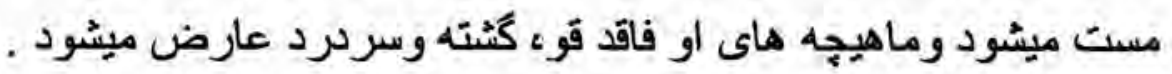

نزد برخى از بيماران زبان بن ميكردد وتا جند ساعت نوانانى فكر كردن را ندارند وانعكاس هاى آنها خيلى كند ميشود ـ كاهى اوقات اين حالات طولانى شُده تأ منتى بيمار

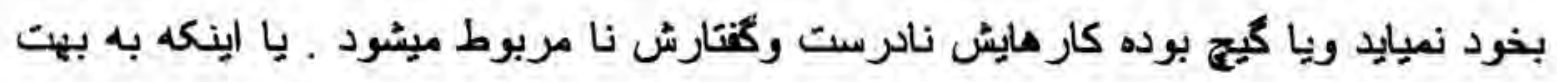

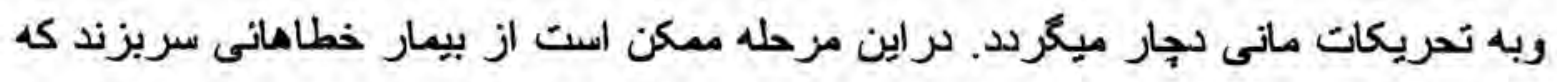
از لحاظ طب قانونى واجد امعيث بوده وتعين مسرليت بيمار خالى از مشكل نميياشد. 
نموحمله : دوام حمله هاى تشنجى عمومى ويا موضعى كوتاه بوده معمولا بيش از يكدقيقه طول نميكثد مكر اينكه جندين حمله بى در بـى بروز كند ودرانى صورت درفاصله حمله هاى بيمار بيهوش يا مبهوت ميماند . حمله هاى بى در بى ممكن است جند دقيقه يا جند ساعت از همه فاصله داشته باشد تعداد حمله ها متفاوت بوده كاهى 3 يا 4 مرتبه در 24 ساعت وزمانى 60 تا 70 مرتبه درشبانه روز تجليد ميشود دراين حالات كه به درد صرعى موسوم شده طول نميكشد كه درجه حرارت بيماز بالا ميرود وزبان خشك و ادرار كم

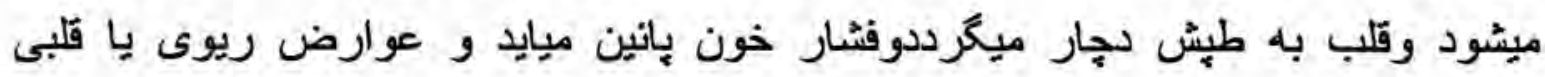
بروزنموده خطر مرى فرا ميرسد .

شدت وفراو انى تظاهرات خفيف يا شديد صرع برحسب اشخاص وطزر زندكى و بهداشت بيمار وعت أصلى ورويه درمان مرض تفاوت ميكند بسا بيمار ان هرجند ماه ى حمله دجار ميشوند ولى بسيارى ديكر هرروز به سه يا جهار حمله دجار ميُّوند واز اينرو ناجار به بسترى شدن دربيمارستان ميكردند كاهى اوقات، مبتلايان فقط دجار سركيجه جزنى بوده ويا هنخام روز شغل خود را ادامه ميدهند.

بيشتر اوقات كودكان بشكل هاى خفيف حمله صرعى دجار ميشّوند اين حمله ها بدون شبب ها بروز ميكند ويس از مدتى صبح ها هنكام بيدارنّن عارض ميكردد و بلاخره برحمله هاى واقعى صرع تبديل ميشود نزد برخى مبتلايان حالات صرعى هميشه يكسان بوده ودرساعات معينى عارض ميگرددونزد بعضى ديكر به هيج وجه رويه ووقت معين نداشته هردفعه بشكلى ودرساعثى بروز ميكند.

سير بيمارى: بيشتر اوقات صرع دركودكى عارض ميكردد وغالبا اطفاليرا كه برحمله هاى تشنجى با بيماريهاى سخت كرفتار شده اند لجار ميسازد هنگام بلوغ وموقع زايمان وثند جوان نيز ممكن است شروع شود. اين بيمارى مزمن بود ويس از شُروع آن اميد

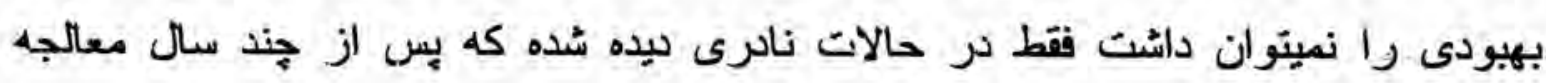
ورعايت بهداشت بهيودى حاصل شده است. 
حالت عمومى مبتلايان به صرع را هنكام يادداشت كرديم دراينجا متنكر ميشويم كه مبتلايان

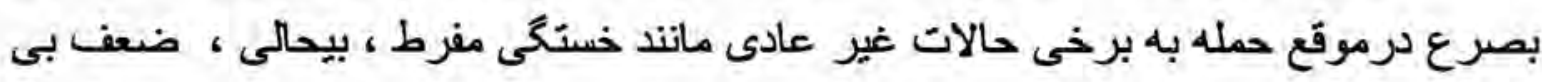

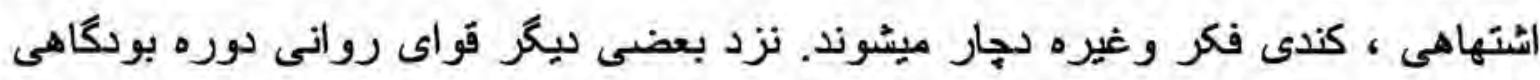
خيلى خوب زمانى بد وبعضى اوقات متوسط است بيمارى كه جند سال است بيمارى مو اجعهل است ودرتحصيلات خود به درجه دكترا ناتل شده واكنون استاد دانشكاه ميياشد كيفيات روحى مختلفه اي احساس ميكند كه آنرا به برجه تقّيم كرده است حالات مذكور بطور

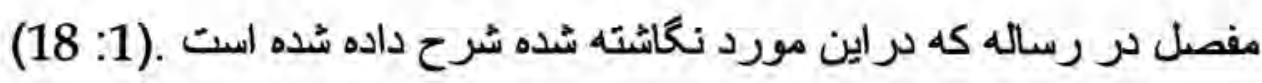

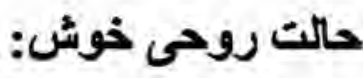

دراينجا همه جيز بيمار خوب جلوه ميكند وخودرا قادر به انجام همه كار مى بيند براى

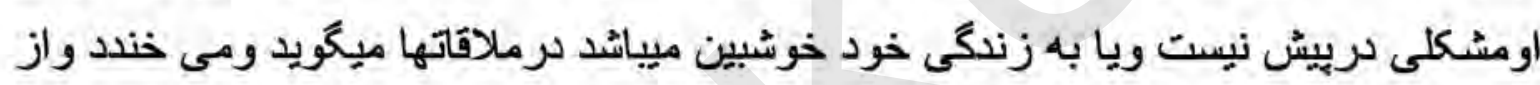

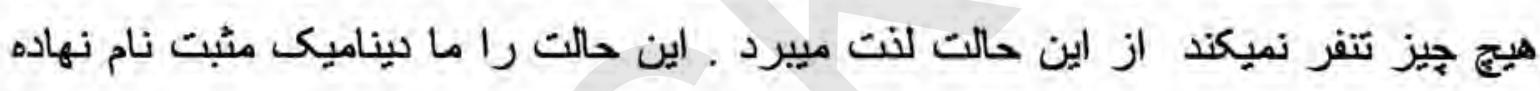

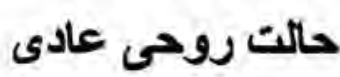

جند روز كه از حالت بيناميك مثبت ميكذرد حال بيمار دكركون شده آن شحف خوشى غير عادى از بين ميرود وكيفيات درنظر او ارزش عادى بيداميكند اين حالت را ماديناميك

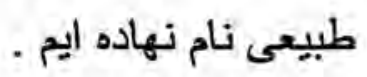

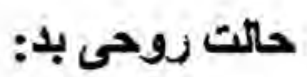

اين حالت بس از حالت عادى ظاهر ميشود

ودرآن بيمار بهه جيز بنيبن شده رمقابل كوجكترين كارها خوري انتوان مى بيند جرات

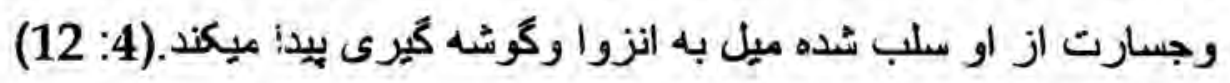


منظور از تداوى به وسيله ادويه عبارت از جلوكيرى ا زوقوع حمله صرع با نكهداشَن

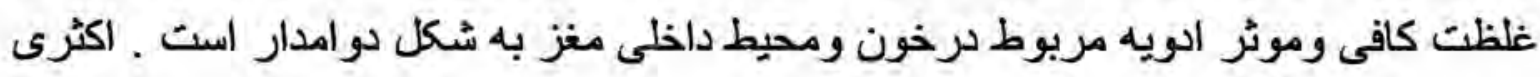
علماى طب تداوى به وسيله ادويه را براى دوتا بنج سال لازم ميدانتد ـ وحداقل براى يكسال ويا حد اكثر هركاه براى دوسال هيج حمله نداشت دواهاى تريجا قطع ثردد. قطع يكى باره دواى صرع سبب توليد حملات شديد و مكرر ميشود مقدار ادويه ازهردو تا جهار هفته كم بـان

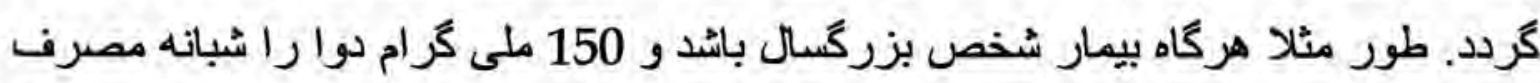

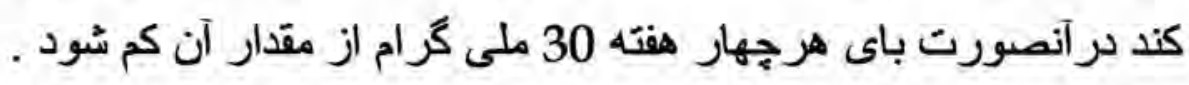

كوشُش شود تا تداوى حملات صرع با مقدار كم دوا شروع شود براى كلان سالان از 40-

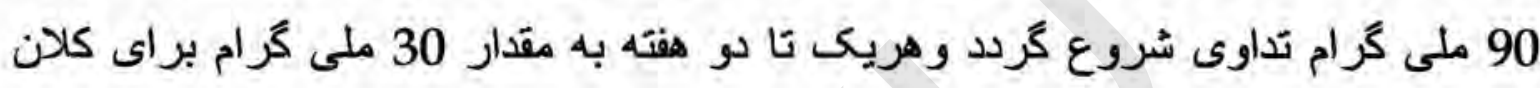
سالان ويكى ملى كرام دريك يا دو هفته براى اطفال به مقدار الويه افزوده شود تا اختّلالات

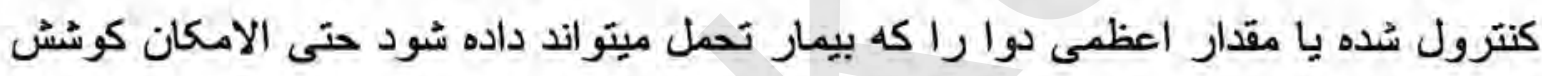

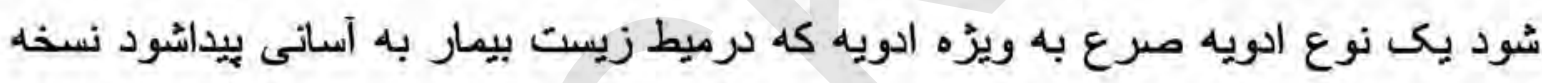
داده شود درصورت نبون ادويه اولى ويا در صورت عدم كنترول حملات ميتوان دواى بـاي

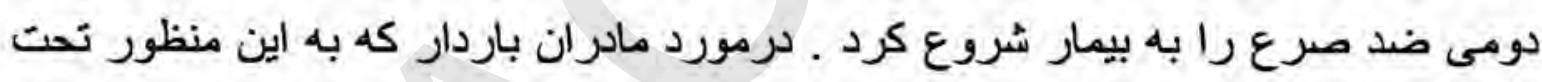
معالجه قراردارند بايد به صورت منظم ودقيق تداوى شوند درصورت برت برد امكان از استعمال

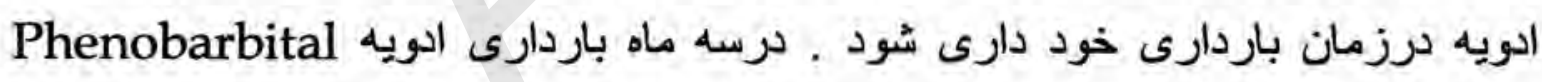
ممكن سبب سوى شكل ولادى شده ودرشش ماه اخير استعمال آن خونريزى نوزاد را بيار

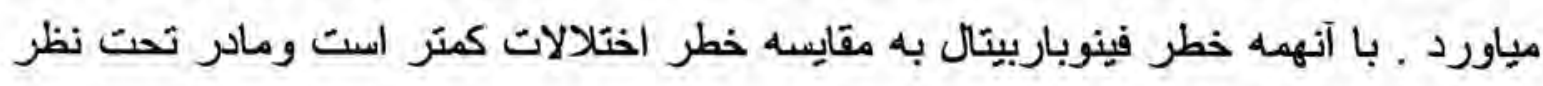
داكتر به كَرفتن اين ادريه ادامه دهد.

برخى از ادويه هاى موثر براى انواع مختلف صرع با عوارض جانبى آن در نيل توزيع ميكردد. 
1. كار با مازين : درتمام انواع صرع به اسنثناى نوع كوجك قابل مصرف ميباشد قطع ناكهانى آن منجر به بروز تشنج و حملات شديد صرعى ميشود لذا توصيه ميشود كه مصرف آن به تنريج قطع كردد. 2. فينوباربيتال : درئمام انواع صرع كوجى وحملات مداوم بكار ميرود همجنان فينوباربيتال زرقى براى درمان آلات اظطر ارى وحملات تشنجى حاد استفاده ميشود بعضى عوارض جانبى اين ادويه حالت خواب آلودگى ، كنسى ، اقسرده كى ذهنى تغيرات رفتار ، مشكلات آموزشى اطفال ، نارامى ، كم خونى و بعضى و اكنشهاى الرزيكى مانند حساسيت يوستى دربزركسالان مياشد. 3. فينى تويى : دركترول تمام انواع صرع به استثناى صرع كوجى استفاده ميشود

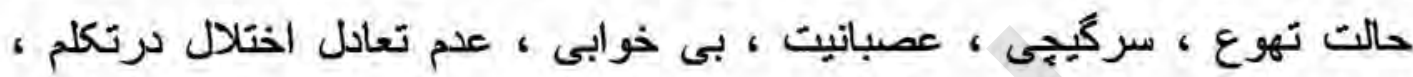
حركات مداوم وغير ارادى جشّم از عوارض جانبى آن ميباشد . 4. بريميدون : درتداوى حملات تشنجى صرع بزرگ مصرف ميكردد. حالت خواب

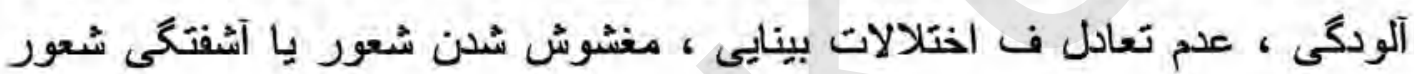
دربزرگسالان ، هيجانات و فعاليت زياد وغير ارادى دراطفال از عوارض جانبى ، اين ادويه ميبانُد.

هدف از تداوى آنست كه از حملات بيشترجلوكيرى كردد. زيرا حملات بيشتر خطر صدمات مغزى بيشتر را با خود دارد. همجنان خطر ات وصدمات به زندكى اجتماعى بيمار رخ ميدهد ـ. استعمال دواها از تعداد ومدت زمان حملات ميكاهد . طوريكه اشاره شد هركاه يك ادويه براى بيمار موثر نباش داكتر مجبور است دواى ديخر را تجويز كتد . كاهى هم بيمار ضرورت دارد تا مجموع جند دوا را مصرف كند . مكر بيشتر از 70 فيصد بيمار ان صرع صرف با يكى ادويه تدارى شُه ميتو اند.

تغغر خصوصيات روانى درنتيجه ابتلا به صرع:

رباره تغيرات كه صرع رخحوصيات روانى ايجاد ميكند نظريات مختلف وجود دارد. طوريكه بعضى از دانشمندان به اين موضوع معتَد اند كه اكر حملات مرع متداوم باشد

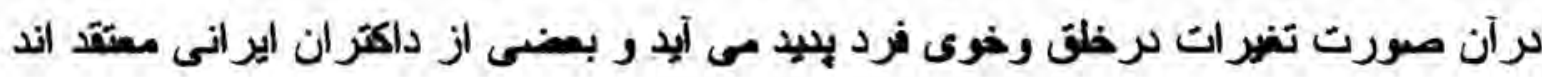


كه باقى ماتن ائرات صرع درشخصيت وتيب ذاتى انسان تاثير فراوان دارد. دانشمند ديكر معنقّ است كه اصولاً برخى ا زعوارض ونشانه هاى ارثى موجب آماده كى به حفظ عوارض صرع درشخص ميكردد و استعداد بنيرش امر اض را درشخص افزايش ميخشند . اين دانثمند د وتيبّ را مستعد صرع ونكهداشتن عوارض آن ميداند.

اول همان تيبى كه "كرجمر" آنرا نام تيب (اتلاتيك ) ناميده است يعنى كسانى كه اندام عضلاتى دارند.

دومين سته كه شديدا تاثير بذير اند وبه جزيى ترين عامل عكس العمل شديد نشان ميدهند

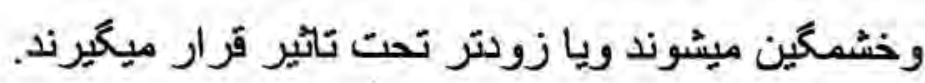

به نظر اين دانشمند درساختمان مغزى آنها دراثر وراثت تغيراتى منفى به وجود مى ايد وبه همين علت بيش از حد معمول اثر بذيراند.

\section{تدابير مراقبتى براى مريضان صرع:}

درشرايط موجود ممكن است از وقوع بيُ از 80 فيصد حملات صرع جلوكيرى كردد ربيك تعداد از واقعات بوسيله تداوى ميتواند از شيت وكثرت حملات صرع كاست

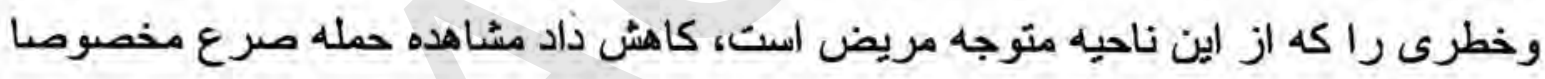

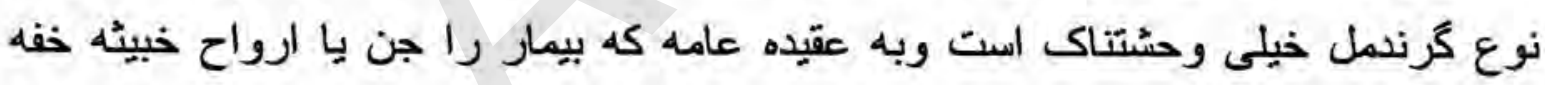

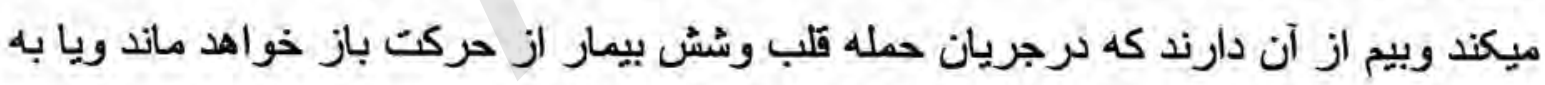

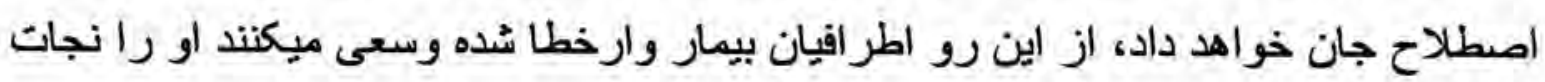
sis

كاهى به جيق وفرياد برداخته كوشُش ميكند بيمار را بيدار با به هوش آورند ويا كاهى

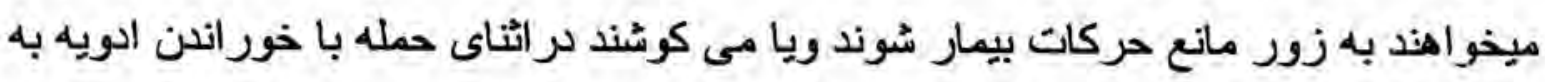
او كمى كنتد درحاليكه تمام اين تدابير غير ضرورى است مر قدم نخست بايد بيمار واقارب نزبيك او درمورد جكونكى صرع وحالات اختلالى معومات داشته باشند وبراى نزبيكان 
بيمار تفهيم شود كه هرنوع كوشش براى بيدار كردن ومحكم كرفنن بيمار تاثير ناكوار بر روحيه او ميكذارد.

لازم است اعضاى خانواده تشويق به ادامه خريد دوا حتى بعد از قطع حملات كردند جون بدون استفاده دوا ممكن حملاث دوباره ادامه يابد.

همجنان اعضاى خانواده ها بايد بفهمند كه شخص مصاب به صرع ميتو اند زندكى عادى و فعال داشته كار نمايد وشتكيل خانو اده دهد.

اعضاى خانواده بيمار وشخص بيمار بايد بدانند كه مرگى بيمار عادى مثل يك حاثث ميكروبى شده كُش يا ساير بيمارى ها ميياشد كه در ائر جن ويرى به وجود نمى آيد بلكه ا

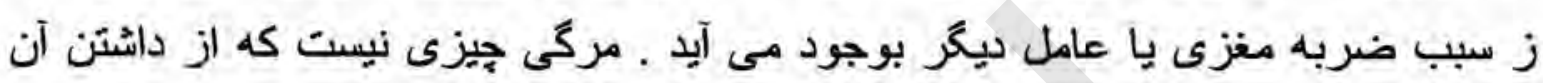
خانو اده يا شخص بيمار شرمنده وخجالت زده شوند .

هنكام حمله دردهن بيمار جيزى كذاشته نشود مثلا نبايد با قاشق يا جسم سخت ديكر براى باز كرن دهن مريض كوشش شود شايد درجريان همجو يك تلاش به دهن و نندانهاى مريض آسيب برسد.

براى بيماران صرع تفهيم كردد كه لحظه ابى بيشتر از وقوع حمله آكاهى مى يابد بهتر است تا تكه باك را در دهن كرده وفوراً بنشيند ويا اكر كسى در نزديكى او باشد ، بهتر است اشياى سخت مانند ظروف ، جوكى ، منقل واشياى برنده را از اطر اف او دو نمايند تا هنكام

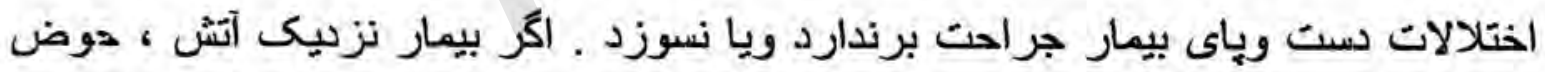
ويا دريا ، جاه ويا جاهاى مرتفع باشد بهتر است بدون وارخطايى وست وياجه شدن اورا به جاى مصون انتقال داد تا وقتى كه حملات تعث كنترول نيامده نبايد رانندىى كند. بعد از ختم حمله بهتر است ، اورا آرام كذانت تا به طور عادى بيدأر گردد. بعضى از

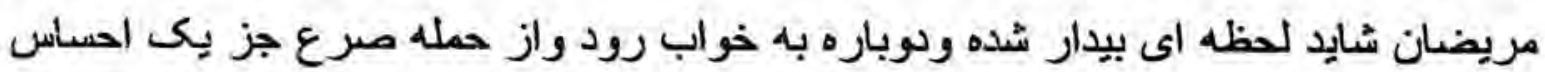
كسالت وكنسى جيزى نفهمند.

هركاه اختلالات بعد ازينج نتيقه توقف نكند، بيمار بايد به نزيك ترين مركز صحى رسانيده شرد 
صرع مانع ادامه تحصيل نميشود ونبايد دراستخدام اشخاص مصاب به كار هاى عادى به حيث كارمند وكارگر تبعيض نشان داد ركسانى كه حمله صر ع به وسيله ادويه كنترول شُه. باشُد مانند شخص سالم درهمه مسايل با او معامله صورت كيرنونبايد شخص مصاب هميشه تحت تعقيب ومراقبت قرار كيرد بهزر است مصابين صرع به كلينيك هاى مخصوص وخمات صحت روانى معرفى وثبت نام گردند تا از ادويه ومشوره هاى لازم استفاده نمايند.

نزد بسيارى از مردم سوال وجود دارد كه آيا مصابين صرع مبيتوانند كه ازدواج كنند يا خير? جواب اين سوال منبت است يعنى اينكه حملات كنترول شُه صرع در شخص با ازدواج وداشتن اطفال دوباره از كنترول خارج نميشود ولى در صورتيكه زن وشوهر هر دو مصاب به صرع باشند ، خطر مصاب شُن اطفال شان به اين بيمارى افزايش مى يابد كه اين تناسب نشان ميدهد كه تعداد افراد مصاب به صرع در جنين حالات بيشتر از آن مِيُود كه فرد عادى جامعه به آن مواجه است. 
موضوع كه دراين رساله مورد تحقيق ويزروهش قرار كرفته يك دوره مشخص صرع با مركى وانواع آنرا احتوا ميكند.

صرع به معنى از خود بيخود شدن ونام عارضه است كه دانشمندان مغرب زمين آنرا ابى ليسى Epliepsy نام نام نهاده است صرع از قِيم ترين وقت به عنوان بكى مرض شناخته شده است كه البته اولين بار اين بيمارى توسط امبرو Emborw نزد دانشمندان رومى بنام (مربوس ساسر) يا بيمارى مقس با كولى سياليس ناميده ميشد واين بيمارى از جمله طو لانى ترين امر اض درتاريخ طبابت به مقايسه ساير امر اض ميياشد. همجنان بايد ياد آور شد كه مبدا اين بيمارى به خصوصيات شيطانى نسبث داده اند يعنى فكر ميشد كه ارواح خييثه در مغز اين اشخاص حلول مى نمايد وبعضى از علماى طب

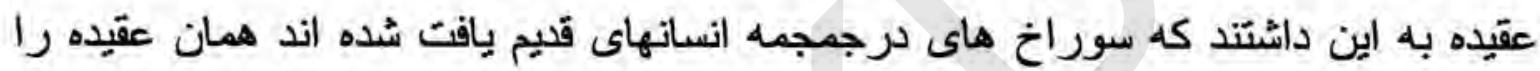
نشان ميدهد كه طبيبان آن زمان به اثر سوراخ كردن جمجمه كسانيكه به مرض صرع كرفتار بوند به اصطلاح ارواح خبيثه را از مغز آنها خارج ميساختند كه ياد آوربايد شد كهانه نامهاى مختلف ونظريه هاى مختلف در قسمت اين بيمارى بيشنهاد شُده است جناتجها ربمحيط ما بنام مرگى مسمى شده است اين مرض امكان دارد در ثمام سنين صورت بكيرد.

حمله ها انواع مختلف دارد كه از آن جمله مينوان حله بزرگ ، حمله كوجى ، حمله قسعى

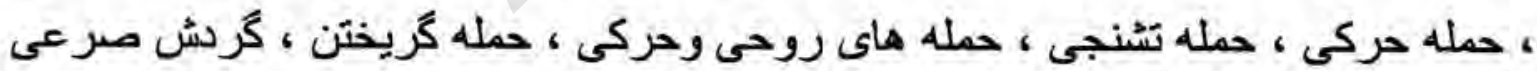
صرع صدغى نام برد.

رخاتمه از دوستان وعلاقمندان مطالعه در مورد انواع صرع وساير موضوعات آن

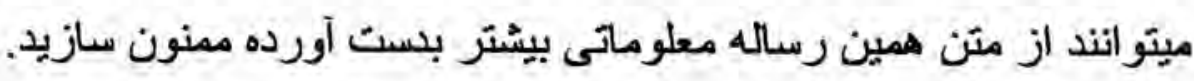




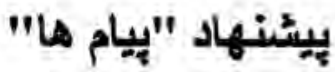

1. بيُّنهاد ميكَردد، كه وزارت صحت عامه بِى كلينيك بخاطر تداوى وجلوكيرى از جنين حملات براى هموطنان ما ايجاد نمايند وادويه شان طور رايكان اجراء شود. 2. داتشمندان داخلى درصورت امكان بايد اثرى ترتيب و بسترس كتابخانه ها قراردهد تا رروقت ضرورت علاقمندان ومحصلان بتو انند از اثر دانشمندان وطن خود استفاده نمايند توفيق مزيد دانشمدان استادان خويش ار دراين مورد خواهانم. 3. وزارت صحت عامه درقسمت ايجاد كلينيك هاى عمومى، بخاطر تداوى همجون امر اض توجه جدى نمايند , ا

4. وزارت صحت عامه از هيج نوع همكارى جهت بهبودى شفاخانه صحت روانى وكمى به روانشاسان وطبييان دريغ نورزند.

5. همكارى منقابل بين يو هنذى ويرسونل شُفاخانه ها صحت روانى جهت يِيُرفت وترقى جانبين وكمى به مريضان روانى بر قرار كردد. 


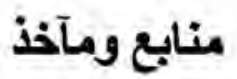

1- ايزدى، سيروس. 1364، روان بزشكى. تهران : انتشار شركت سهامى جهره. 2- ارتور، كايتون، 1347، فيزيولوزى بزشكى. تهران: انتشار اصفهان. 3- حق اليقين، ف نصرت، 1374، راهمانى والدين در فوريثها يزشكى كودكان. تهران: انتشارات اساطير. 4- محمد، بهشتى. 1351، طب داخلى. تهران: انتشار دانشكاه تهران. 5- محمد، صديقى يور. 1353، طب داخلى. تهران: انتشار نوبل سيتريز. 6- منكل، سردار محمد. 1346، آريانا دايره المعارف. كابل: انتشارات مطبعه دولتى. 7- ميرسياسى، عبدالحمين. 1341، رواتيزشكى. تهران: انتشار دانشكاه تهران. 8- فرويد، زيكمويد ويونگ. 1369، اصول ومبانى روانشناسى. تهران: انتشار شهرياد. 


\section{بك رياست محترم بِهنخى و ديبارتمنت محترم روانشناسى!}

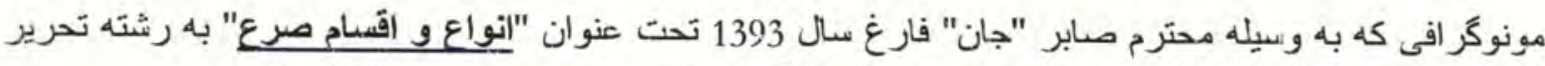

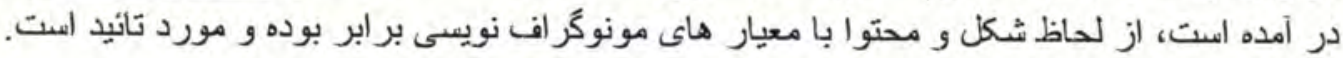

با الحترام

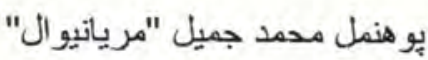

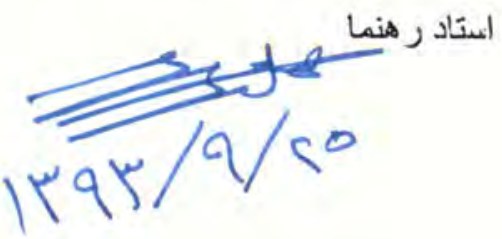

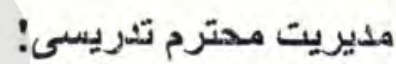

مونوگر اف هذا كه مورد تائيد استاد رهنما قرار كَرفته است. آمريت ديبارتمنت روانشنانى نيز آترا هورد تائيد ميداند.
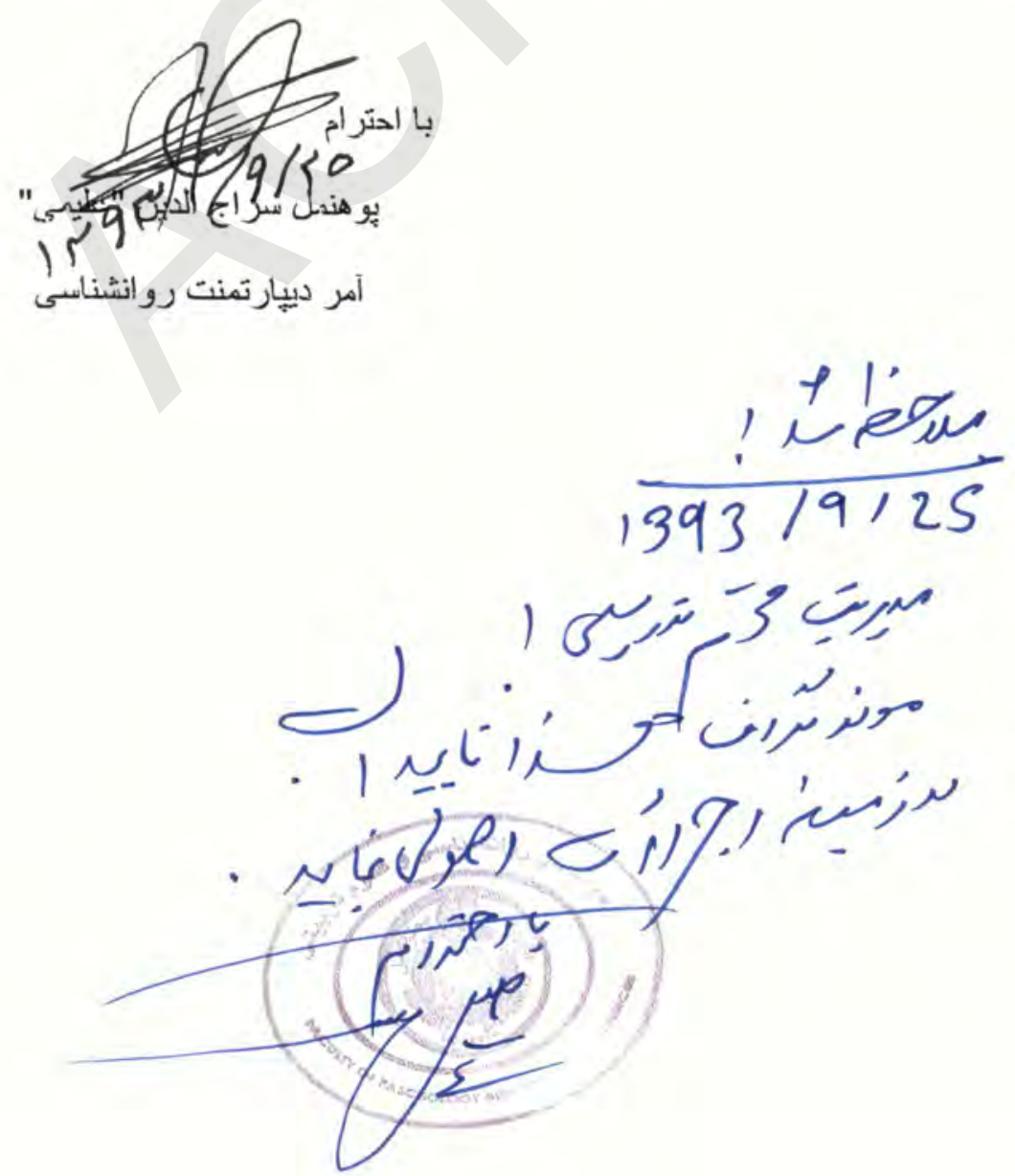